\title{
Chapter 2 \\ Offshore and Multi-Use Aquaculture with Extractive Species: Seaweeds and Bivalves
}

\author{
Bela H. Buck, Nancy Nevejan, Mathieu Wille, Michael D. Chambers \\ and Thierry Chopin
}

\begin{abstract}
Aquaculture of extractive species, such as bivalves and macroalgae, already supplies a large amount of the production consumed worldwide, and further production is steadily increasing. Moving aquaculture operations off the coast as well as combining various uses at one site, commonly called multi-use aquaculture, is still in its infancy. Various projects worldwide, pioneered in Germany and later accompanied by other European projects, such as in Belgium, The Netherlands, Norway, as well as other international projects in the Republic of Korea and the USA, to name a few, started to invest in robust technologies and to investigate in system design needed that species can be farmed to market size in high energy environments. There are a few running enterprises with extractive species offshore, however, multi-use scenarios as well as offshore IMTA concepts are still on project scale. This will change soon as the demand is dramatically increasing and space is limited.
\end{abstract}

\footnotetext{
B.H. Buck ( $₫)$

Marine Aquaculture, Maritime Technologies and ICZM, Alfred Wegener Institute Helmholtz Centre for Polar and Marine Research (AWI),

Bussestrasse 27, 27570 Bremerhaven, Germany

e-mail: Bela.H.Buck@awi.de

B.H. Buck

Applied Marine Biology, University of Applied Sciences Bremerhaven,

An der Karlstadt 8, 27568 Bremerhaven, Germany

N. Nevejan · M. Wille

Laboratory of Aquaculture \& Artemia Reference Center,

Department of Animal Production, Faculty of Bioscience Engineering,

Ghent University, Campus Coupure F, Coupure Links 653, 9000 Ghent, Belgium

M.D. Chambers

School of Marine Science and Ocean Engineering, University of New Hampshire, Morse Hall, Room 164, Durham, NH, USA

T. Chopin

Canadian Integrated Multi-Trophic Aquaculture Network, University of New Brunswick, 100 Tucker Park Road, Saint John, NB E2L 4L5, Canada

(C) The Author(s) 2017

B.H. Buck and R. Langan (eds.), Aquaculture Perspective of Multi-Use Sites

in the Open Ocean, DOI 10.1007/978-3-319-51159-7_2
} 


\subsection{Sustainable Aquaculture}

The development of sustainable aquaculture is aimed at insuring that commercial aquaculture has minimal adverse effects on the environment. One way to achieve this goal is through the development of improved methods of waste management for land based, coastal and offshore aquaculture by combining extractive and fed aquaculture, also referred to as integrated multi-trophic aquaculture (IMTA) systems.

Fish excrete nitrogen (N), phosphorus (P) and carbon (C) (Beveridge 1987; Mugg et al. 2000; Neori et al. 2004, 2007; Corey et al. 2014). Nearly $50 \mathrm{~kg} \mathrm{~N}$ and $7 \mathrm{~kg} \mathrm{P}$ can be released per ton of finfish produced per year (Chopin et al. 1999; Kautsky et al. 1999; Troell et al. 2003; Kim et al. 2013). In coastal waters, high levels of these nutrients can trigger harmful microalgal blooms (red tides) and contribute to excessive growth of nuisance or opportunistic macroalgae (green and brown tides), which in turn have negative consequences on coastal ecosystems and economies. These nutrients could instead be used to support the growth of economically important seaweeds, which would compete for nutrients with nuisance species, especially in nearshore coastal environments, hence mitigating these potentially adverse environmental impacts (Neori et al. 2004, 2007; Chopin et al. 2008; Pereira and Yarish 2008; Abreu et al. 2009, 2011b; Buschamnn et al. 2008; Corey et al. 2012, 2014; Kim et al. 2013, 2014a, 2015a). Seaweeds take up N, P and $\mathrm{C}$, which they use for growth and production of proteins and energy storage products (mostly carbohydrates). When seaweeds are harvested from IMTA or nutrient bio-extraction systems, the nutrients are also removed from the environment. Seaweeds can then be used on for bio-based, high-valued compounds for human consumption, protein sources in finfish aquaculture diets, sources of phycocolloids, cosmeceuticals, nutraceuticals and other biochemicals, and for low-value commodity energy compounds such as biofuels, biodiesels, biogases and bioalcohols (Horn et al. 2000; Smit 2004; Chopin et al. 2011; Cornish and Garbary 2010; Gellenbeck 2012; Kim 2011).

Integration of shellfish with cage culture of fish can also help to reduce the risk of eutrophication since the particulate organic matter (POM) produced by fish (wasted feed and faeces) and the increased plankton production serve as excellent feed and are filtered out by these organisms. Faster growth (between 30 and $40 \%$ greater) of bivalves near fish cages has been reported with contributions of fish feed and fish faeces varying between 5-28\% and 4-35\%, respectively (Wallace 1980; Jones and Iwama 1991; Stirling and Okomus 1995; Buschmann et al. 2000; Lefebvre et al. 2000; Lander et al. 2004; Peharda et al. 2007; Chopin et al. 2008; Sara et al. 2009; Handå et al. 2012; Jiang et al. 2013; Dong et al. 2013). Other studies, however, did not observe a difference in growth near fish cages (Mazzola and Sara 2001; Navarrete-Mier et al. 2010). Several explanations for these contradicting results have been given by e.g. Troell and Norberg (1998), Troell et al. (2011), Handå (2012) and Reid et al. (2013): (1) the POM generated by the fish culture doesn't increase the seston concentration significantly due to dilution; 
(2) the shellfish culture infrastructures were not adequately positioned to intercept the POM plume; (3) the POM produced by fish sinks very quickly to the bottom where it is no longer accessible for the filter feeders; (4) shellfish don't adapt fast enough to the pulse feeding system used for feeding the fish; (5) they only filter particulate waste product when the natural plankton production is low; (6) the seston concentration and size reach the limits where pseudo-faeces are produced.

There are limited interactions between seaweed and bivalve cultures as seaweeds feed on inorganic nutrients and bivalves on organic nutrients from the water column and, therefore, can be regarded as co-cultures with separate nutrient models, although the excretion of metabolic waste products by bivalves enhances the availability of inorganic nutrients (Jansen 2012).

\subsection{Introduction to Extractive Species}

Marine extractive species include a large variety of species, which can be subdivided into three main groups among animals and algae: (1) filter feeders, such as oysters and mussels, (2) deposit feeders, such as polychaetes, sea urchins and sea cucumbers, as well as (3) dissolved nutrient absorbers, such as microalgae and macroalgae. These species act as living filters and can be raised without supplemental feed as they take up nutrients for nourishment from the surrounding water column. While filter and deposit feeders preferentially use small and large POM for their nutrition, algae extract dissolved inorganic nutrients (DIN) from the water column. The POM mainly consists of naturally occurring seston and uneaten fish feed, faeces and bacterial matts in aquaculture operations. The dissolved fraction consists of inorganic nitrogen $(\mathrm{N})$, phosphorus $(\mathrm{P})$ and carbon $(\mathrm{C})$ available from nature and released from fed aquaculture operations. As deposit feeders are not yet often used in offshore environments or in multi-use platforms, they are not discussed further within this chapter.

\subsection{IMTA on Offshore Applications}

There have been technology exchanges between Asian and western countries. For example, traditional seaweed cultivation technologies have been exported from Asia to the West, while the concept of ecosystem services (Costanza et al. 1997) has been transferred to Asia. Scientists in Asia and the West are integrating these technologies to increase production in an environmentally friendly manner. In turn, bivalve cultivation was mainly developed in Europe (and to some extend in New Zealand) and expertise and technology were transferred to North and South American countries, as well as Asia, Australia and countries in the Pacific Ocean.

One conceptual approach driven by the various stakeholders using coastal waters is to transfer aquaculture operations away from nearshore areas. Moving the 
production of seaweeds and bivalves off the coast in offshore environments could solve spatial and environmental problems currently existing in coastal seas. The production of extractive species in offshore areas could solve the global issue of providing large amounts of biomass to the end user. There are several reports available examining the feasibility of moving seaweed and bivalve aquaculture towards the more hostile environment of the open ocean, in combination or not with offshore structures. Nevertheless, plans to connect such culture devices to offshore foundations of wind turbines are still in their infancy (Buck and Krause 2012). A non-exhaustive list is presented below:

- 2000: Open Ocean Aquaculture within Offshore Wind Farms. A Feasibility Study Concerning the Multifunctional Use of Offshore Wind Farms and Offshore Aquaculture within the North Sea (Buck 2002)

- 2004: Farming in a High Energy Environment: Potentials and Constraints of Sustainable Offshore Aquaculture in the German Bight (North Sea) (Buck 2004, 2007)

- 2012: Integration of Aquaculture and Renewable Energy Systems (Buck and Krause 2012)

- 2013: Short Expertise on the Potential Combination of Aquaculture with Marine-Based Renewable Energy Systems (Buck and Krause 2013)

- 2013: Aquaculture in Welsh Offshore Wind Farms: A Feasibility Study into Potential Cultivation in Offshore Wind Farm Sites (Syvret et al. 2013).

- 2013: Triple P Review of the Feasibility of Sustainable Offshore Seaweed Production in the North Sea (van den Burg et al. 2013)

- 2014: Combining Offshore Wind Energy and Large-Scale Mussel Farming: Background \& Technical, Ecological and Economic Considerations (Lagerveld et al. 2014)

- 2015: Go Offshore-Combining Food and Energy Production (Carlberg and Christensen 2015)

- 2015: Aquaculture Pilot Scale Report (TROPOS 2015).

\subsection{Extractive Species Aquaculture}

\subsubsection{Seaweeds}

Seaweeds are part of the cultural heritage of Asian countries, much more so that in Western countries. Nevertheless, according to a recent archaeological study, cooked and partially eaten seaweed were found at a 14,000-year-old site in southern Chile, suggesting seaweeds have been part of human diet for a very long time and in other parts of the world as well (Dillehay et al. 2008). Global seaweed aquaculture production represents $49.1 \%$ of total world mariculture production by weight, with an annual value of US $\$ 6.4$ billion (FAO 2014; Chopin 2014). From an estimated 
10,500 species of seaweeds, only six genera provide $98.9 \%$ of the production and 98.8\% of the value: Saccharina, Undaria, Porphyra, Gracilaria, Kappaphycus and Sargassum. Unfortunately, not much of that is produced in the Western World as 96.3\% of seaweed aquaculture is concentrated in six Asian countries: China (with over 54.0\% of production), Indonesia, the Philippines, the Republic of Korea, Japan and Malaysia (Chopin 2014). Currently a total of 54,000 t of seaweed have been cultivated in the Americas and Europe with an annual value of US \$51 million in 2013 (FAO 2016a, b), which is even less than the value that Korea exported to the U.S. in the same period (US $\$ 67$ million; Meekyiung Kim, Korea Agro-Trade Center pers. comm.). Seaweed production in the Americas and Europe is still in its early stages compared to the vast production in Asia. Although seaweed aquaculture is a fairly new industry in the Americas and Europe, the market demand is expected to increase rapidly due to an increasing consumer demand for new protein sources and healthy food supplements and the food industry's interest in sustainable textural additives (Buchholz et al. 2012).

There are some characteristics that will foster the production of seaweed worldwide. They provide ecosystem services, which need to be recognized and valued appropriately (Chopin 2014). One often forgotten function of seaweeds is that they are excellent nutrient scrubbers and can be used for nutrient biomitigation of fed aquaculture or other sources of nutrification. Seaweeds can be cultivated without the addition of fertilizers and agrochemicals, especially in an IMTA setting, where the fed aquaculture component provides the nutrients. Seaweed cultivation does not require more arable soil and transformation of land for agricultural activities with accompanying loss of some ecosystem services. If appropriately designed, it can be seen as engineering new habitats and harboring thriving communities, and can be used for habitat restoration. Moreover, it does not need irrigation, on a planet where access to water of appropriate quality is becoming more and more an issue. As photosynthetic organisms, seaweeds are the only aquaculture component with a net production of oxygen. All other fed and organic extractive components are oxygen consumers. Hence, seaweeds contribute to the avoidance of coastal hypoxia. While performing photosynthesis, seaweeds also absorb carbon dioxide and hence participate in carbon sequestration, even if in a transitory manner. Consequently, they could be a significant player in the evolution of climate change, slowing down global warming, especially if their cultivation is increased and spread throughout the world. By sequestering carbon dioxide and increasing $\mathrm{pH}$ in seawater, seaweeds could also play a significant role in reducing ocean acidification at the coastal level (Clements and Chopin 2016).

The IMTA concept (Chopin et al. 2001; Troell et al. 2003; Neori et al. 2004; Chopin 2006) is a good illustration of how to take advantages of the ecosystem services provided by extractive species and fits very well within the concept of circular economy (Pearce and Turner 1989). Moreover, seaweed production doesn't compete with other food productions while delivering new biomass flows for 
animal feed, food, and non-food products (Buck 2004). For instance, sugars, proteins and fatty acids (principally omega 3s) from seaweeds can form an alternative to soya and fishmeal. Further, the use of seaweeds for the production of chemicals and biofuels could be a climate-friendly alternative to fossil raw materials.

Seaweed aquaculture technologies for land based, as well as sheltered nearshore areas, have developed dramatically in Asia and to a lesser extend in South America. In contrast, technologies to move offshore were developed in Americas and Europe over the last 15 years. There are still challenges to overcome, which vary depending on species, technologies and countries. In Europe, mainly kelps were tested in first offshore trials during the early 1990s (Lüning and Buchholtz 1996). France and Germany were the first investing countries for offshore seaweed cultivation followed by UK and Ireland, 10 years later. Today, the Netherlands, Denmark, Spain, Portugal, as well as Norway, are carrying out seaweed farming trials off the coast. Most of the investigations are still carried out on a pilot scale. Only a few farms off the coast are in early commercial operations, such as enterprises in Germany (e.g. CRM 2001), Norway (e.g. SES 2015a, b), and The Netherlands (Hortimare 2016).

\subsubsection{Bivalves}

In 2014, the annual production of bivalves, including mussels and oysters, reached approximately 7 million $\mathrm{t}$, which is equivalent to one quarter of the annual seaweed production (approximately 27 million t) (FAO 2016a, b). In Europe, the blue mussel (Mytilus edulis) and the Mediterranean mussel (Mytilus galloprovincialis) are the main cultured species reaching approximately 500,000 $\mathrm{t}$ annually. The main producers are Spain $(220,000 \mathrm{t})$, Italy $(80,000 \mathrm{t})$, France $(75,000 \mathrm{t})$, the Netherlands $(55,000 \mathrm{t})$, the UK $(23,000 \mathrm{t})$ and Germany (6000 t) (FAO 2016a, b). Other important countries outside of Europe producing mussels are China (800,000 t), Chile $(240,000 \mathrm{t})$, Thailand $(125,000 \mathrm{t})$, South Korea $(52,000 \mathrm{t})$, New Zealand $(38,000 \mathrm{t})$, Canada (26,000 t), Brazil (20,000 t) and the Philippines (19,000 t). In 2014, approximately 5.2 million t of oysters were produced worldwide, dominated by the Pacific oyster (Crassostrea gigas). In Europe, the introduced Pacific oyster reaches $\approx 90,000 \mathrm{t}$ headed by France with $\approx 75,000 \mathrm{t}$, followed by Ireland with $9000 \mathrm{t}$, the Netherlands with $\approx 2500 \mathrm{t}$ and Norway with $\approx 2000 \mathrm{t}$. Other countries outside of Europe are China with $\approx 4.3$ million $t$, South Korea with $\approx 285,000 \mathrm{t}$, Japan with $\approx 185,000 \mathrm{t}$, the USA with $\approx 125,000 \mathrm{t}$, the Philippines, Taiwan and Thailand with $\approx 22,000 \mathrm{t}$, and Australia and Canada with $\approx 12,000 \mathrm{t}$. The European flat oyster (Ostrea edulis) is cultured to a minor extent only with approximately $2500 \mathrm{t}$ in 2014 led by France and followed by Ireland, Spain and the Netherlands (FAO 2016a, b). 


\subsection{Cultivation Technologies, Challenges and Future Directions in Major Cultured Extractive Species}

Below we provide some basic information on the cultivation of red and brown macroalgae to allow a better understanding of the entire production cycle. Mussel and oyster cultivation methods are explained as well. However, as this book is mainly focusing on the future development of extractive species off the coast we do not go in detail with the complete reproduction of these species and will describe further the cultivation only with regard to the transfer offshore and its relevance to modern technical design. Further information into the biology and cultivation can be gained by reading the literature on fundamental seaweed and bivalve biology and ecology, such as Kim (2012), Wiencke and Bischof (2012) and Hurd et al. (2014) for seaweeds, as well as Matthiessen (2001), Gosling (2003) and Shumway (2011) for bivalves.

\subsubsection{Red Seaweeds}

\subsubsection{Pyropia and Porphyra ('Gim' in Korean or 'Nori' in Japanese)}

Although a total of 138 species of Pyropia and Porphyra are currently accepted taxonomically (Guiry and Guiry 2015), only 4 major species (Py. yezoensis, Py. tenera, Py. haitanensis and Po. umbilicalis) have been cultivated, mostly in China, the Republic of Korea and Japan (99.99\% of total production) and to some extend in the USA and Europe (FAO 2016a, b). The culture methods of Pyropia/Porphyra in these three Asian countries are basically similar, with minor modifications (Sahoo and Yarish 2005; Pereira and Yarish 2008, 2010). For example, some farmers use free-living conchocelis for seeding while others use conchocelis on oyster shells (He and Yarish 2006). Seedlings may be outplanted in the open water farms using one of three cultivation methods: fixed pole, semifloating raft, or floating raft (Sahoo and Yarish 2005). The epiphyte control techniques are also different, based on the cultivation techniques. Most Chinese farms, and some Korean and Japanese farms use desiccation control methods by exposing the Pyropia/Porphyra nets to the air to kill epiphytes and competing organisms (e.g. Ulva spp.), while most Korean and Japanese farmers use the more efficient $\mathrm{pH}$ control method by spraying organic acids onto the nets (Pereira and Yarish 2010; Kim et al. 2014b) which is, however, more costly. The uncontrolled fouling organisms reduce the quality of the product. Recent reports suggest that the world's largest macroalgal blooms of Ulva prolifera are trapped on rafts of Pyropia farms in the Southern Yellow Sea of China (Liu et al. 2009; Zhang et al. 2014, 2016) before moving towards the Qingdao region. The initial propagules may, however, 
originate further south on the large intertidal radial mudflat in the Jiangsu Province where they find favorable conditions, enriched by nutrients discharges from coastal land-based animal aquaculture, before developing into green tides (Liu et al. 2013). In mid-1990s, Coastal Plantations International attempted to cultivate Pyropia (Porphyra) in the open waters of Maine, USA (Chopin et al. 1999; McVey et al. 2002) but was unsuccessful for economic and managerial reasons. More recently, Porphyra umbilicalis cultivation in Maine has been taken up by Brawley and her colleagues (Blouin et al. 2011). A seaweed manual has been published for seedstock production of Pyropia/Porphyra in the USA (Redmond et al. 2014) with accompanying videos in English. However, Pyropia/Porphyra cultivation is still in its nascent stage in North America and Europe commercial enterprises. Therefore, it is critical to develop local cultivars and cultivation techniques suitable for the local environments and boutique markets. Selective breeding (intra-specific and inter-specific) of cultivated Pyropia/Porphyra has been intensively studied in Asia (Miura 1984; Shin 1999, 2003; Niwa et al. 2009). Genetic improvement has resulted in superior strains with higher growth rates, better flavor, darker color and higher tolerance to diseases (Chen et al. 2014).

Since 1880, Earth's average surface temperature has risen by about $0.8{ }^{\circ} \mathrm{C}$ and the majority of that warming has occurred in the past three decades (NASA 2015). Recently, NASA and NOAA reported that 2014 ranks as Earth's warmest year since 1880 . The 10 warmest years since records were registered, have occurred since 2000, with the exception of 1998. Therefore, development of new strains with high thermo-tolerances will be necessary for the development of a sustainable seaweed aquaculture industry. With current technology, six to eight harvests can be obtained from the same nets during one growing season. Expansion of the growing season by using new strains will, therefore, result in higher production for growers. These current and developing cultivation technologies for Porphyra/Pyropia can be used for offshore cultivations. Simulation programs such as the hydrodynamic simulation program ANSYS-AQWA are useful tools to analyze the dynamic characteristics of a seaweed culture system (Lee et al. 2013).

\subsubsection{Brown Seaweeds}

\subsubsection{Saccharina and Undaria}

Kelps have been utilized mostly for human consumption, but recently it's been increasingly utilized as abalone feed thanks to relatively low production cost (Hwang et al. 2013). For example, over 60\% of the total production of Saccharina and Undaria in the Republic of Korea was used in the abalone industry in 2012.

In western countries, kelp species (primarily the sugar kelp, Saccharina latissima) have been cultivated during the last two decades in the Atlantic Ocean (e.g. USA, 
Canada, Norway, Scotland, Ireland, Sweden and Germany; Buck and Buchholz 2004a, 2005; Chopin et al. 2004; Barrington et al. 2009; Broch et al. 2013; Marinho et al. 2015; Kraemer et al. 2014; Kim et al. 2015a) and Macrocystis in the eastern Pacific Ocean (e.g. Chile; Buschmann et al. 2008). The kelp aquaculture industry in western countries has become one of the fastest growing industries.

For both Saccharina and Undaria, cultivation begins with zoospores (meiospores) for seeding. The seeding methods are a bit different between Asia (use of seed frames) and the West (use of seedspools), mainly due to the nursery capacities and the scale of operations of the open water farms (Redmond et al. 2014). However, the open water cultivation techniques use very similar longlines. Once the seedstring is outplanted in the open water farms, the kelp thalli will grow up to 2-5 m in length, even to $10 \mathrm{~m}$ sometimes (Pereira and Yarish 2008; Redmond et al. 2014).

Facing climate change, many efforts are deployed to develop kelp strains that grow fast, are resistant to disease and tolerate higher temperatures. Selective breeding and intensive selection of kelp strains in Asia, however, have reduced the genetic diversity and narrowed the germplasm base of the varieties in cultivation. This has led to decreased adaptability of these varieties to environmental changes and jeopardizes the industry expansion in Asia (Kawashima and Tokuda 1993; Li et al. 2009; Robinson et al. 2013). In North America and Europe, strain development will be a challenge. The collection of zoospore "seeds" has relied mostly on wild sources. Development of a seedbank for kelp species will provide a sustainable and reliable source of seedstock without impacting the natural beds of seaweeds. Having seaweeds with desirable morphological and physiological traits will also enhance production capacity of the seaweed industry. Other challenges in these parts of the world are the legal aspects and the social syndrome known as NIMBY ("Not In My Back Yard"). For example, in the USA at least 120 federal laws were identified that affect aquaculture either directly (50 laws) or indirectly (70 laws) and more than 1200 state statutes regulate aquaculture in 32 states (Getchis et al. 2008). Regulatory complexity is further increased when towns or counties are given jurisdiction over local waters. Social resistance has also been a major factor limiting the growth of aquaculture in the USA. The nearshore waters of the USA are heavily used, having both recreational (boating, fishing, swimming) and aesthetic (ocean and bay views from waterfront homes) values. For that reason, offshore cultivation has been suggested as an alternative to avoid stakeholder conflicts (Langan and Horton 2005; Rensel et al. 2011; Buchholz et al. 2012).

Since nutrients may be limiting in offshore environments, an IMTA systems may be more appropriate than monoculture (Troell et al. 2009; Buchholz et al. 2012). Considering current cultivation techniques, the kelp species should be one of the most appropriate groups to cultivate offshore due to their low maintenance requirement and ease of harvest in comparison to other cultured species. The IMTA practices of offshore farms are unlikely to experience user conflicts, which may result in fewer restrictions on farm size and greater economies of scale. 


\subsubsection{Sargassum}

Sargassum is the most common brown macroalgae found in temperate, tropical, and subtropical waters worldwide with more than 346 species (Guiry and Guiry 2015). Sargassum species have traditionally been utilized for food and medicine in Asia. They continue to be wild harvested and cultivated in Japan, China and the Republic of Korea, for human consumption as sea vegetables and for use as a medicinal "seaweed herbs". Locally known as the "black vegetable" in China, Sargassum is valued for its high nutritional content and nutty flavor. It is added to salads, soups or vegetable dishes (Xie et al. 2013). Sargassum is utilized in Chinese medicine as an expectorant for bronchitis, and to treat laryngitis, hypertension, infections, fever, and goiter (Hou and Jin 2005). Sargassum fusiforme (formally "Hizikia fusiformis") cultivation was initiated in the early 1980s. Thus, the production and economic value is still low, approximately 150,000 t of production with an annual value of US \$70 million in 2013 (FAO 2014). Nearly all Sargassum production takes place in China, including several species such as $S$. thunbergii, $S$. fulvellum, $S$. muticum, and $S$. horneri (Xie et al. 2013). In the Republic of Korea, $S$. fusiforme and S. fulvellum are being cultured (Hwang et al. 2006).

Traditional culture methods initially relied on the use of wild seedlings collected from natural beds. Groups of 3-4 seedlings, 5-10 $\mathrm{cm}$ in length, were inserted onto seeding ropes at intervals of $5-10 \mathrm{~cm}$. These smaller seeding lines were then attached to a main longline placed at depths of 2-3 m, and cultivated from November to May (Sohn 1998; Hwang et al. 2006; Redmond et al. 2014). This dependency on wild seedlings resulted in the overharvesting of natural beds, so new culture methods were developed. Holdfast-derived seeding was the first step towards developing more efficient culture techniques for Sargassum. This type of culture takes advantage of the perennial nature of the holdfast, allowing farmers to reuse the holdfasts from the previous year's crops (Hwang et al. 1998). While plants may still be sourced from wild beds, the attached holdfasts can be re-used for the next season's crop by over-summering in the sea after harvest until the next growing season. While this allows for reuse of existing cultured plants, the resulting harvestable biomass tends to diminish after each year. Today, Sargassum lines are seeded with juvenile plants obtained from reproductive adults. Obtaining seedlings through sexual reproduction allows for mass production of new plants for seeding, and results in higher biomass yields (Hwang et al. 2007; Peng et al. 2013; Redmond et al. 2014). Fertilized eggs are gathered from mature fronds and "seeded" onto seed string by allowing juveniles to attach to seed lines with newly forming rhizoids. Once attached, seedlings are cultured in a nursery until ready for out-planting at sea, where they are transferred to submerged long lines until harvest. The attached holdfasts can also be re-used for multiple years without any further initiation of culture ropes. This is an economically reasonable cultivation method, but there are problems with fouling organisms. New technologies to reduce fouling problems are in urgent need for the sustainability and growth of the Sargassum aquaculture industry. 
Sargassum is also an appropriate species to cultivate offshore. It even has certain advantages over kelps, such as a higher market value (\$500 per $t$ ) and the unique cultivation technology of using a perrenating holdfast for multiple years.

\subsubsection{Bivalves}

\subsubsection{Mussels}

Mytilids present a high fecundity and the larval phase is mobile and free-living, a fact that facilitates a widespread distribution. The culture technique used is greatly influenced by the seed availability. Mussel culture worldwide is mainly relying on wild seed, either by capturing competent (=ready to settle) larvae by means of mussel seed collectors or by fishing young mussel seed $(2 \mathrm{~cm})$ from natural mussel banks, which is predominantly applied in The Netherlands, Germany and Denmark.

Mussels can be farmed on-bottom or off-bottom. On-bottom culture is based on the principle of transferring wild seed from areas where they have settled naturally to areas where they can be placed in lower densities to increase growth rates, and that facilitate harvest and predation control (Seed and Suchanek 1992; Seaman and Ruth 1997). Off-bottom cultivation methods includes (1) the bouchot method, where piles with seeded mussel ropes are planted in the intertidal zone and mussel spat grows to market size, (2) rafts, where ropes are seeded with young mussels and suspended vertically from a floating raft construction, and (3) longline culture, where mussel spat is attached to vertical ropes, called seed collectors, or on continuous ropes (e.g. New Zealand), which hang on a horizontal backbone including floating devises to support buoyancy (Buck et al. 2006b). Seed collectors may consist of coconut fiber ropes placed in the intertidal zone (France), short polyethylene droppers from rafts (Spain), specially designed collector droppers with increased surface (e.g. "christmas tree"), fixed on longlines or collector nets (e.g. Smartfarm ${ }^{\circledR}$ ). Production time from settlement to market size depends very much on the species and production location (temperature and phytoplankton concentration) but varies between 18 and 36 months.

Longlines and raft systems are the two commonly and most successfully used mussel-farming systems. The longline system consists of one to two suspended horizontal headlines made of $12-15 \mathrm{~cm}$ polypropylene rope about $100-220 \mathrm{~m}$ in length and anchored at both ends. Single headlines are sometimes preferred as the gear required to lift and harvest a single line is far more economical and less labor intensive. The headlines are connected to large floats (usually of plastic, each with about $300 \mathrm{~kg}$ displacement), which together support a large number of $5 \mathrm{~m}$ culture droppers (ropes). The number of droppers used varies with hydrological and biological conditions but is normally in the order of 400-500 per (double headline) longline. Secure anchoring is necessary to prevent the longlines shifting in heavy seas or strong currents. In soft bottom sediments, traditional concrete or steel anchors of $250-500 \mathrm{~kg}$ are used. Depending upon the amount of movement 
encountered, one or two anchors are placed at the end of headlines. At exposed sites, a mid-anchor may be needed to control movement and stretch; screw anchors may also be used to maintain the position of the longline. Continuous seeding of entire loops of culture rope over $200 \mathrm{~m}$ long-rather than $5 \mathrm{~m}$ lengths - is now common and was invented in New Zealand. Harvesting has also become mechanized: one machine lifts and strips the ropes, washes, separates and packs the mussels into bags. Longlines may be sunk to greater depths to reduce aesthetic objections. The aquaculture area can then be shared with recreational fishing and pleasure boats. Raft culture is similar in many respects to longline culture, except that the raft commonly swings on a single mooring. As with longline culture, ropes are suspended from the raft. Most harvesting is done by hand since this technique has far less scope for mechanization, but over the last decade, mechanization also started. Raft culture in Europe is typically found in Spain. The operations generally are smaller in scale compared to longlining ones. However, the raft does provide a valuable depot structure.

Mussel spat is rarely produced in hatcheries because the production cost relative to the market value of the commercial product doesn't justify the effort. There are exception though along the West coast of USA and Canada (British Columbia) where the introduced blue mussels Mytilus edulis and M. galloprovincialis are being produced in hatcheries. Currently, the largest larval production takes place in Nelson (New Zealand) for New Zealand green-lipped mussels, Perna canaliculus.

\subsubsection{Oysters}

Oysters can also be cultured on- and off-bottom. Off-bottom cultivation strategies include (1) lantern nets, where oysters are placed in little bags suspended in the water column, or (2) poche culture, where the oysters are stuffed in bags, which are put on metal frames along the beach at low tide, and finally (3) in trays (Buck et al. 2006a). These systems are places on the seafloor or are deployed in a suspended manner below longline or other floating carrying devices as mentioned in the previous paragraph.

\subsection{Current Status of Offshore Seaweed and Bivalve Production and Their Potential for Multi-Use}

When looking at the offshore production of extractive species in a multi-use concept, it can be concluded that most projects were conducted in Europe and some others in Asia and the USA. In this section we provide a review on the potential and constraints of offshore seaweed and bivalve research and production in terms of biology, technology, and system design, as reported for different countries. 


\subsubsection{Germany}

Germany is one of the leading countries in offshore seaweed science with first trials of moving seaweed operations offshore in the early 1990s. Therefore, the developments conducted in Germany are discussed in detail in another chapter (Chap. 11 "The German Case Study" within this book) while here, we only provide a short summary.

Seaweed aquaculture research at offshore sites in Germany started in 1992 with longline, ladder, grid and ring constructions (Lüning and Buchholz 1996) (Fig. 2.1a-d). Next to designing systems, research focused on reproduction, seeding strategies, growth performance and site selection (Buck and Bucholz 2004a, 2005; Lüning and Buchholz 1996).

Laminarian species seem to be the most robust species with offshore aquaculture potential in the North Sea, followed by Palmaria and Ulva. First experiments on laminarian species showed that they adapt to strong currents after being transferred at sea as young individuals. The offshore plants grew well at these exposed sites (Buck and Buchholz 2004a, b, 2005).

(a)

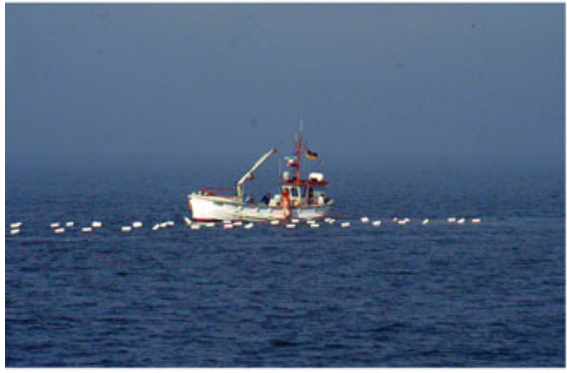

(c)

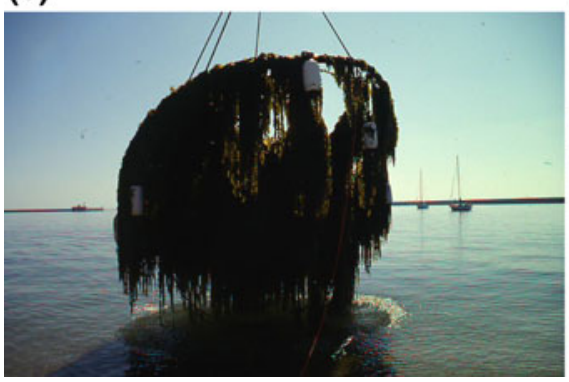

(b)

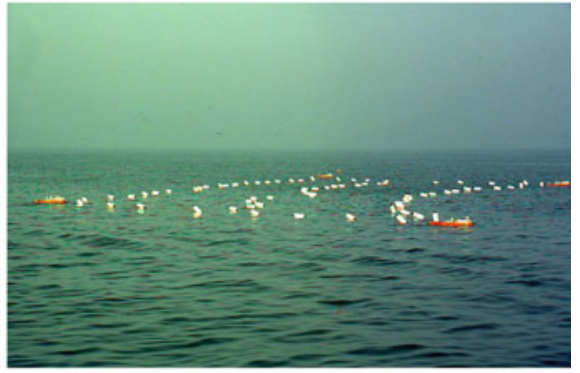

(d)

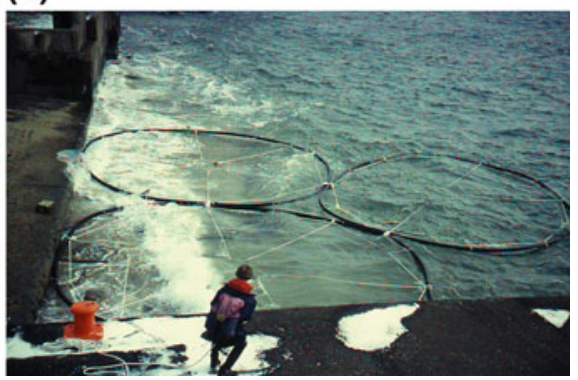

Fig. 2.1 (a-d): a shows the first offshore ladder construction (double longline) for hostile environments (Lüning and Buchholz 1996); b displays a grid construction off the offshore island of Helgoland; c shows a ring construction at harvest; d shows the ring construction in a multi-modular mode. Images (a-d) AWI/Cornelia Buchholz 
The technology (Fig. 11.32 and 11.33 in Chap. 11 "German Case Study") used at that time was modified in terms of easy handling (deployment, maintenance, harvesting), robustness and connectedness to the foundations of offshore wind farms. Unfortunately, the longline and grid systems installed in harsh offshore conditions were not robust enough as there was a considerable stress on support material and algae during floatation mode (Lüning and Buchholz 1996; Buck 2004; Buck and Buchholz 2004a, b). As the idea of utilizing the foundations of offshore wind generators for the fixation of aquaculture systems is intriguing, these co-use concepts were the main driver to keep on working with seaweeds offshore infrastructures (e.g., Buck 2002; Krause et al. 2003; Buck et al. 2004). As a consequence, the ring construction was modified several times until it reached its final design and resisted any kind of possible sea condition in the North Sea. This offshore ring device is the first modern structure worldwide that enables mass seaweed cultivation on an industrial scale in the world's oceans. Another seaweed project led by German scientists plans to integrate Saccharina latissima cultures within a projected wind farm in Nantucket Sound (Massachusetts, USA) (Buck et al. 2011).

Mytilid larval appearance and settlement of Mytilus post-larvae at offshore test collectors, which were placed in the vicinity of offshore wind farms in the German Bight, were suitable for spat collection as well as for grow-out (Buck 2017). However, at some offshore test sites grow-out has to be economically calculated, as settlement might not be sufficiently dense. Mussels (Mytilus edulis) and oysters (Ostrea edulis) were successfully cultivated in and in the vicinity of the wind farms Nordergründe (17 nautical miles off Bremerhaven) and Butendieck (ODAS, 14 nautical miles off the Island of Sylt), as well as in North-South and West-East transects crossing all potential wind farms in the German Bight (Brenner et al. 2007; Buck 2007, 2017; Buck et al. 2006b). Health conditions with regard to infestations of macro-parasites, fitness and growth performance for both species were excellent (Pogoda et al. 2011, 2012, 2013; Brenner et al. 2007, 2012, 2014). Various technical solutions to connect submerged infrastructures to a windmill foundation or to deploy it centrally into a wind farm area were worked out (Buck 2007; Buck et al. 2006b, see also Chap. 11 "German Case Study"). To measure the forces impinging on the entire backbone, wave and current load cells were integrated in the system and artificial test bodies were used (Fig. 2.2a-f). Economic feasibilities studies were carried out as well as a protocol for a one-step mussel cultivation method that doesn't require any thinning procedure till reaching market size (Buck et al. 2010). 
(a)

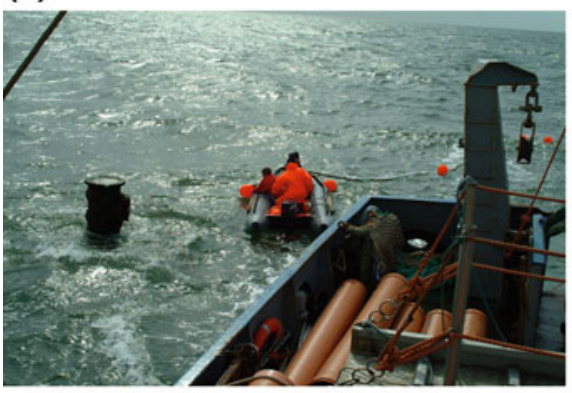

(c)

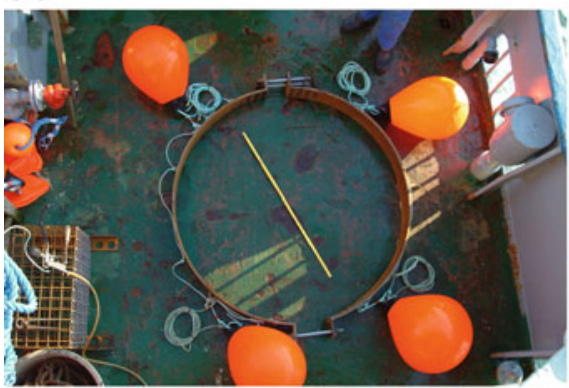

(e)

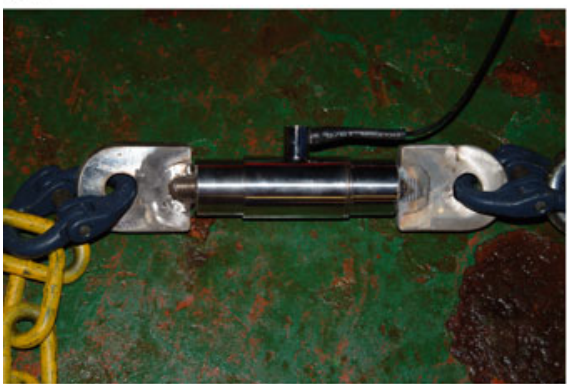

(b)

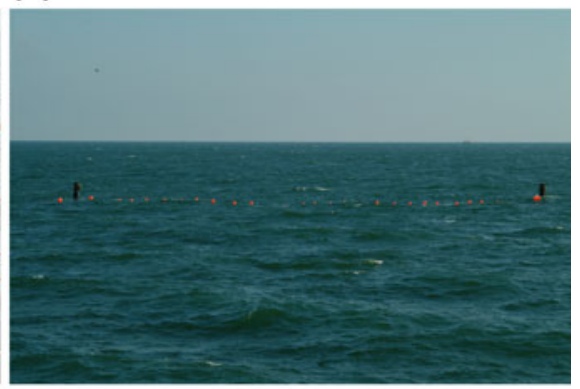

(d)

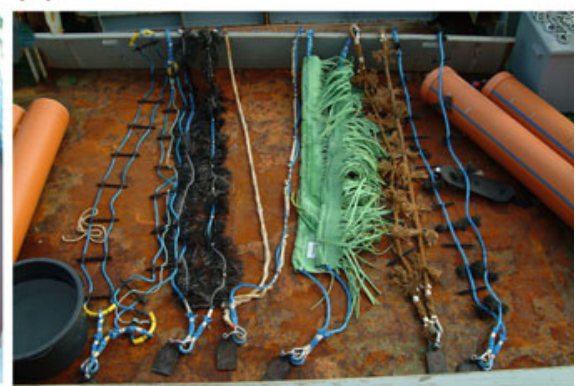

(f)

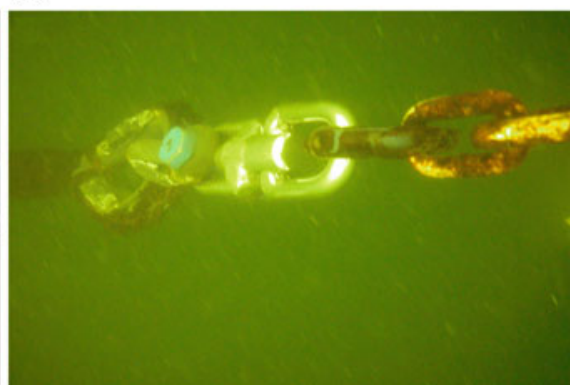

Fig. 2.2 (a-f): ODAS test site 14 nautical miles off the coast of the island of Sylt. a Displays the set-up of parts of the longline to an offshore test pole (symbolizing the foundation of an offshore wind turbine); b shows the floating buoys marking the submerged longline; $\mathbf{c}$ demonstrates the connection piece from the foundation to the holding device at one end of the submerged longline; d shows different spat collectors as well as artificial test bodies; and underwater load cells e on board of the vessel as well as $\mathbf{f}$ in operation under water

\subsubsection{Belgium}

The Belgian part of the North Sea is more or less $3454 \mathrm{~km}^{2}$, or represents only $0.5 \%$ of the total surface of the North Sea. The coastline is only $65 \mathrm{~km}$. Depth reaches a maximum of $45 \mathrm{~m}$. 
(a)

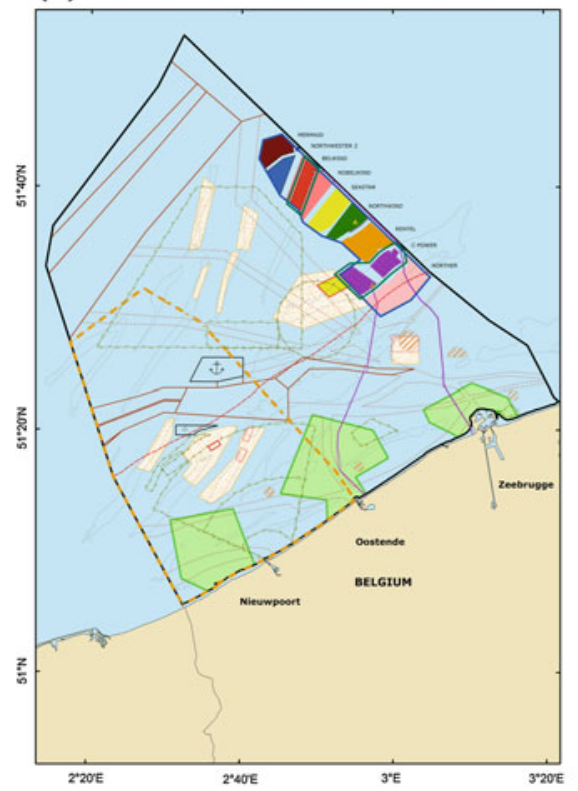

(b)

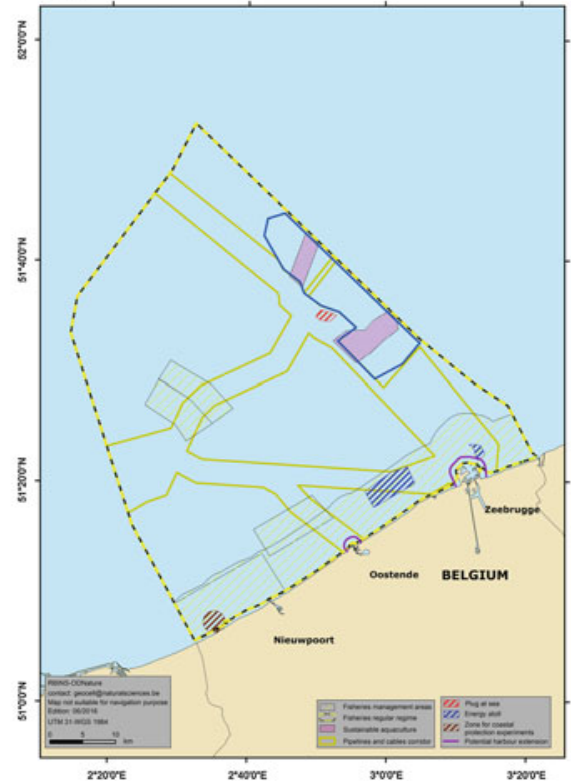

Fig. 2.3 (a-b): location of wind energy concessions (a) and aquaculture zones (b) in the Belgian part of the North Sea (Vigin et al. 2016)

In early 2014, a new Marine Spatial Plan (MSP) was introduced that outlines which activities can take place where and under which conditions. The plan is valid for a period of 6 years until 2020, after which modifications can be introduced. According to the MSP, commercial aquaculture is only possible in two zones which fall within the concessions for wind energy: the concessions of C-power (zone 1) and Belwind (zone 2), which are located on the Thorntonbank and the Bligh Bank, respectively (Fig. 2.3). Aquaculture in these zones needs to fulfill two requirements: (1) the owner of the wind energy concession has to approve and (2) the aquaculture activity contributes to the reduction of the eutrophication levels of the concession zones.

Between 1997 and 2011, there were several initiatives to culture the blue mussel M. edulis in the Belgian part of the North Sea. The summary of events given below is based on information collected from personal communication with Willy Versluys and the interim report of The Institute for Agricultural and Fisheries Research (ILVO) (Delbare 2001). Starting in 1998, several production systems and mussel seed capture devices were tested. One of the first designs consisted of a longline of $200 \mathrm{~m}$ with anchors of $1 \mathrm{t}$ at each end. Every $10 \mathrm{~m}$ there was a float to carry the V-shaped, $5 \mathrm{~m}$ long mussel ropes. Mussels were allowed to settle on the ropes and stayed there until market size. Pegs prevented the biomass of sliding (Fig. 2.4a). Six of these structures with a total length of $1200 \mathrm{~m}$ were hung at sea 
(a)

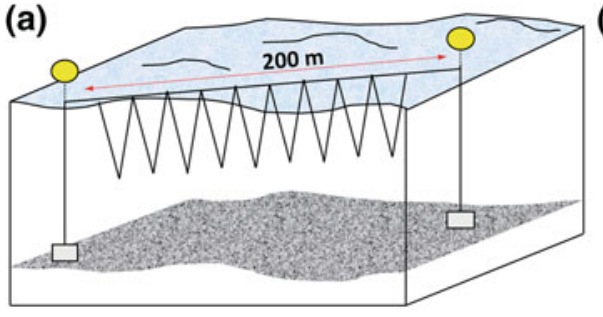

(c)

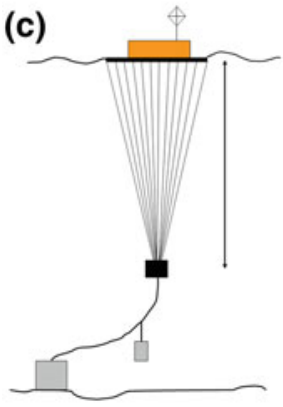

(b)

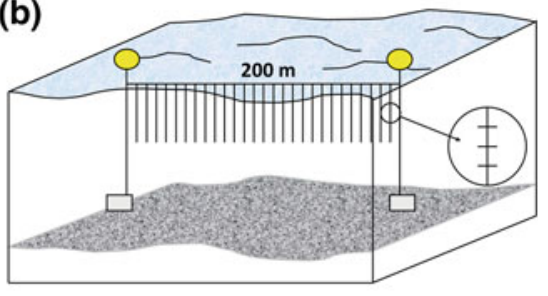

(d)

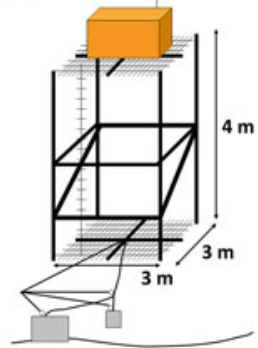

(e)

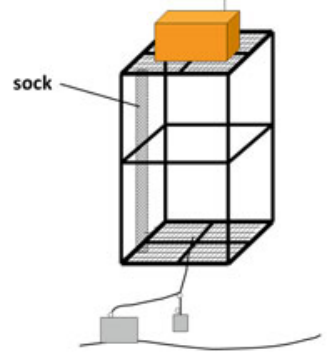

Fig. 2.4 (a-e): a construction of a mussel hang culture (used in 5b project 1998); b construction for spat collection (used by José Reynaert in 2001); c-d Hang culture system with and without closed frame (used in Pesca-Project 2000) e construction for grow-out. Graphics: Delbare (2001)

(location: top of Buitenratel) but were destroyed by boat traffic. Mussel growth results were, however, promising.

In 2000, a more robust construction was developed for the zone D1 (zone of $0.09 \mathrm{~km}^{2}$, north of Noordpas, near buoy D1, extension of sandbank Smal bank, $13 \mathrm{~km}$ of the coast at Nieuwpoort) where boat traffic is not allowed. A first design consisted of the floating frame with 45 mussel ropes of $10 \mathrm{~m}$ whose ends were attached at one point. A weight prevented the ropes of friction against each other and to get entangled (Fig. 2.4c-d). The whole construction was anchored with a heavy weight and foreseen of a contra-weight to compensate for the tugging. Later, it was decided to include a closed frame so the whole construction could be lifted at once into the boat. By the end of 2000, however, the cages were lost due to insufficient anchoring and floating devices.

In 2001, two different systems were designed for mussel seed collection and grow-out. To capture mussel seeds, a longline of $200 \mathrm{~m}$ with floats was anchored by means of two anchors of $1 \mathrm{t}$ at each side, in the zone D1. A total of 20 polypropylene ropes of $5 \mathrm{~m}$ length and $12 \mathrm{~mm}$ thickness were attached to the longline (Fig. 2.4b). The grow-out system consisted of floating cages with socks hung inside (Fig. 2.4e). Despite the prohibition for boats to enter the D1 zone (quite shallow), more than half of the longlines were destroyed and the grow-out cages dislodged by boat traffic. Mussels grew very well on the sunken cages, reaching a size of 6-7 cm in 10 months, despite the high densities. From 2002 to 2006, José Reynaert continued his endeavor with private money and with scientific support 
(a)

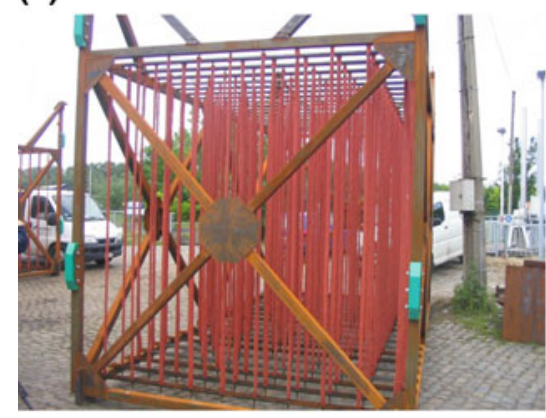

(b)

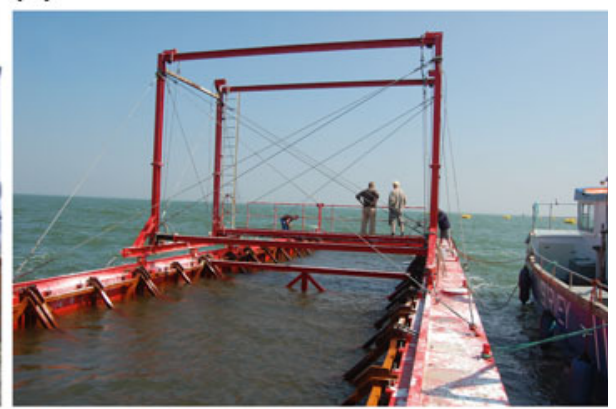

(c)

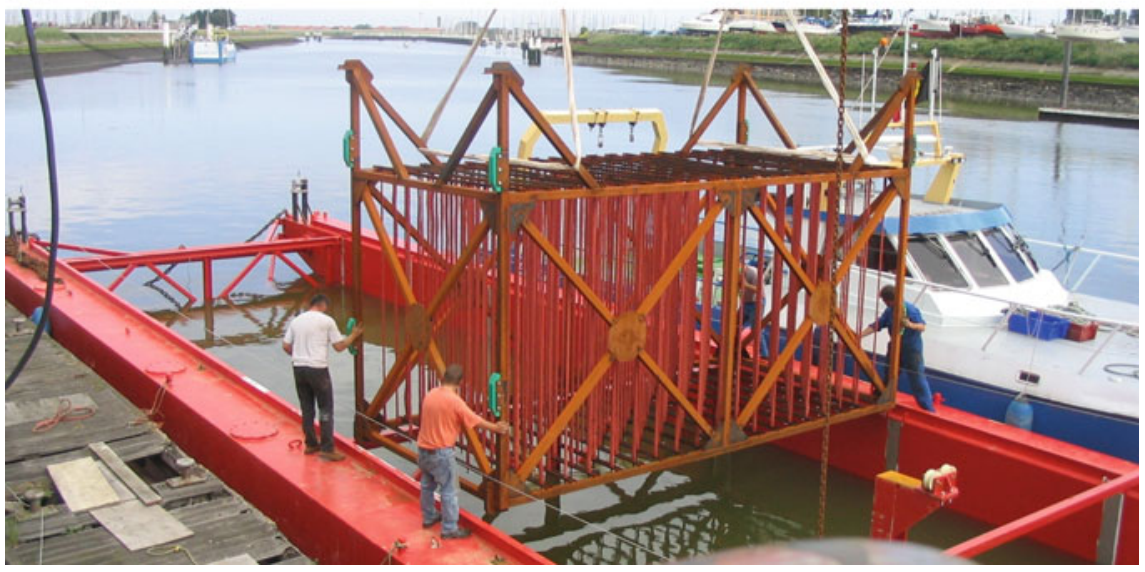

Fig. 2.5 (a-c): culture system for the "Belgica Mussel" in 2009: here, the aquaculturist worked with floating pontoons because of the shallow depth and strong currents. a Metal frame as holding device for the mussel collectors, b view from the front panel, c transfer at sea. Photographs (a) and (c) Willy Versluys; (b) Kris Van Nieuwenhove

from Ilvo. He developed a floating cage that contained several frames with mussel ropes that could slide in and out of the cage. Results have not been communicated.

This system was further improved in 2009 by Reynaert and Versluys. It became a floating pontoon with 8 cages (Fig. 2.5a-c). Each cage contained 160 hollow plastic tubes of $3 \mathrm{~m}$ which served not only as pole around which the mussel socks were wrapped but they also increased the buoyancy of the construction (Fig. 2.5c). The cages measured $34 \mathrm{~m}$ by $8 \mathrm{~m}$ and remained $3.4 \mathrm{~m}$ above the water and $5 \mathrm{~m}$ under the water. However, the pontoon soon twisted under the increasing weight of the growing mussels, making it impossible to lift the cages out of the frame for harvesting or maintenance. Mussels were harvested in June-July and the quality was high. The mussels were commercialized as the "Belgica" mussels. Production did not meet the expectations because of technical problems and in 2008 the whole crop had to be destroyed because of a suspicion of diarrhetic shellfish poisoning (DSP). 

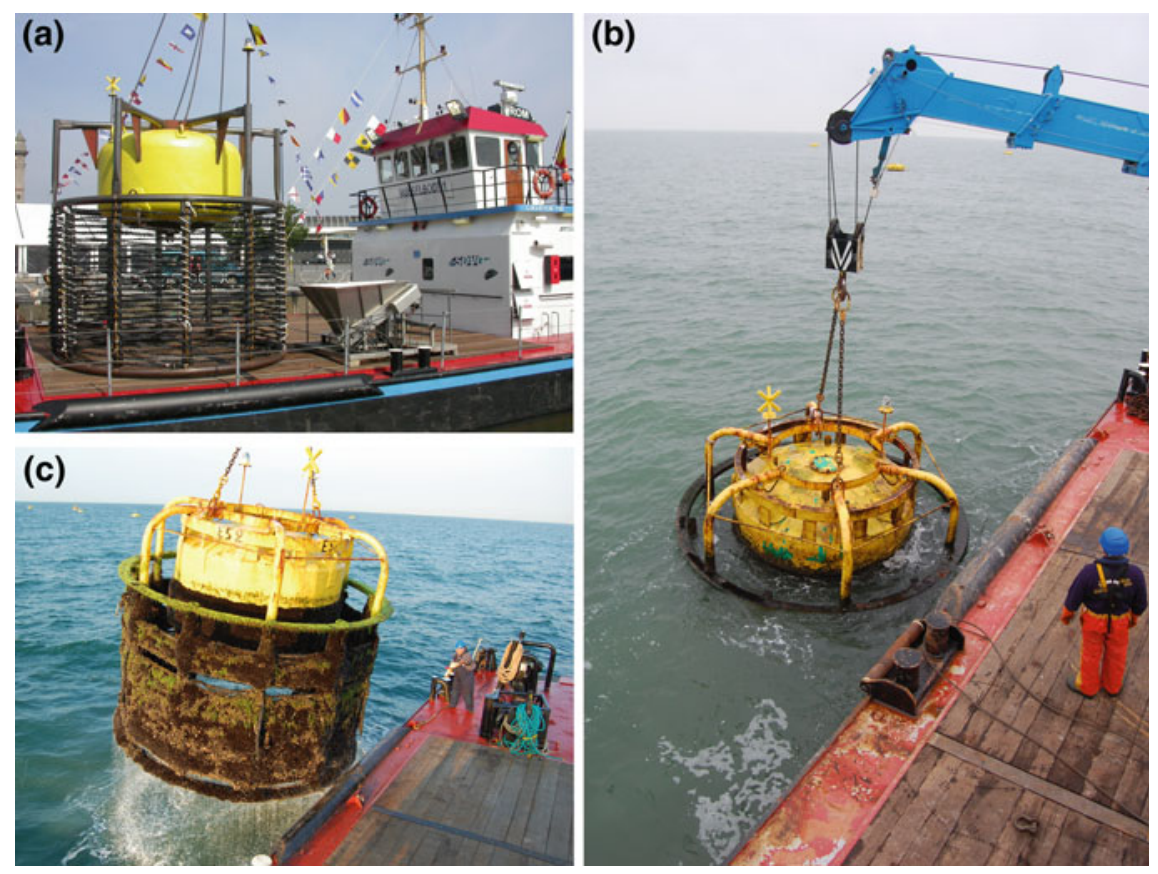

Fig. 2.6 (a-c): Buoy-collector-system used by SDVO (2005-2010); a device on board of the deployment vessel, b-c collection mussel buoy at deployment. Photograph Kris Van Nieuwenhove

Between 2005 and 2010, another subsidized project started independently in the Belgian North Sea and was carried out by Stichting voor Duurzame Visserijontwikkeling (SDVO). They developed round floating buoys with mussel ropes wrapped around them (Fig. 2.6a-c). More than one hundred of these buoys were put in the sea but data on production are not available. A large number of these devices got lost or were swept onto the beach. The mussels were commercialized as the "Flandres Queen Mussel". All efforts were stopped in 2010.

In conclusion, there is quite some experience in mussel culture in open sea in the Belgian part of the North Sea. Despite the fact that all the constructions proved themselves to be inadequate to deal with the rough North Sea conditions, the experiments demonstrated that the biological and chemical conditions in open sea along the Belgian North Sea coast are very suitable for growing mussels. The harvested mussels were of excellent quality and could be harvested earlier than the mussels of the Netherlands, the major supplier of mussels to Belgium. Obtaining natural spatfall was also never a problem.

Designing a right infrastructure and anchoring system that guarantees a reliable mussel production, that can cope with the very rough conditions of the North Sea and that offers enough protection against boat traffic is the big challenge for the future. In 2017, a new project ("Edulis") will explore the possibilties to grow blue mussels and collect blue mussel seed (both Mytilus edulis) in the windmill parcs 
C-Power and Belwind, making use of semi-submerged longlines (backbone $58 \mathrm{~m}$ ) that will be held in place by weight anchors at a depth of $5 \mathrm{~m}$ under the surface. The project is mainly funded by private partners and coordinated by Ghent University, Laboratory of Aquaculture \& Artemia Reference Center with the support of the Alfred-Wegener-Institute (AWI) in Germany. At the same time, another initiative, Value@sea will start growing seaweeds (Undaria pinnatifida, Saccharina latissima and Porphyra sp.) in combination with different species of bivalves closer to the Belgian coast (in front of Koksijde). It will use submerged longlines (backbone $100 \mathrm{~m}, 1.5 \mathrm{~m}$ under the surface) which will be secured with screw anchors. Again, this project is largely supported by the private sector and coordinated by Ilvo.

\subsubsection{Norway}

Regarding the cultivation of seaweeds, the report "A new Norwegian bioeconomy based on cultivation and processing of seaweeds: Opportunities and R\&D needs" (Skjermo et al. 2014) discusses the use of seaweed cultivation in offshore environments as one of the opportunities. When moving off the coast, the authors evaluate the best opportunity for the seaweed industry to co-use existing offshore structures, such as wind farms. One driver for the preparation of this study was the existing problems associated with vast amounts of nutrients originating from salmonid farms. In 2011, the Norwegian Research Council funded a project called SWEEDTECH, which looked into the development of a cost efficient system in order to start with large scale offshore seaweed cultivation. This project also included seaweed seeding strategies, development of carrier material, design and development of a structural rig as well as the development of alternative deployment and harvesting methods (SES 2015a, b). As an outcome of SWEEDTECH and as a result of the current development of seaweed cultivation off the coast of Norway, AquaCulture Engineering AS (ACE) and SINTEF Fisheries and Aquaculture will establish a new site of 3 ha with an expected yearly production of $1500 \mathrm{t}$ of laminarian macroalgae (ACE 2015).

The company Seaweed Energy Solutions AS (SES) was involved in concepts to upscale seaweed cultivation off the coast (Bakken 2013). As a consequence, SES patented (SES 2015a) the first modern structure to enable mass seaweed cultivation on an industrial scale in Norway. This structure, called Seaweed Carrier (Fig. 2.7a-e), is described as being a sheet-like structure that basically copies a very large seaweed blade, moving freely back and forth through the sea from a single mooring on the seabed. The carrier can withstand rough water, has few moving parts, has low cost and allows for easy harvesting. The way the carrier has been put into practice to date has been limited to two major tangible prototypes (SES 2015b): (1) A semi-rigid truss prototype (90 m long) with 8 carrier nets of $50 \mathrm{~m}$ width and 5-10 $\mathrm{m} \mathrm{depth}$, which had been developed for energy-scale, fully mechanized operations. This undertaking is, however, presently suspended. (2) A flexible hybrid long line system for semi-exposed water, as used in the $100 \mathrm{t}$ pilot project in Frøya. The carriers were 

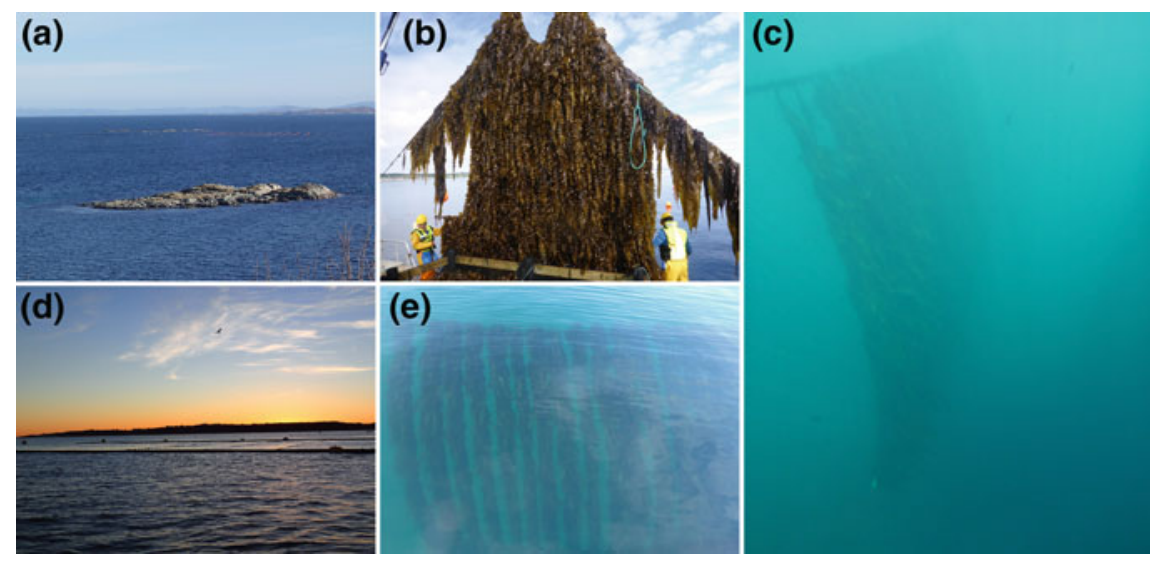

Fig. 2.7 (a-e): $\mathbf{a}$ and $\mathbf{d}$ Site of the installation off the coast of Frøya; $\mathbf{b}$ harvest of seaweed growing on the Carrier; $\mathbf{c}$ and e underwater image of the kelp growing on the carrier devices; all images provided by SES (2015a, b)

attached as $6.5 \mathrm{~m}$ long and $5 \mathrm{~m}$ deep two-dimensional flexible units and showed very good growth. One single longline operated as a backbone for 20 of these carriers. Until today, a mechanization of the process has not been implemented due to lack of funds. SES focus is now to pursue a gradual development of this aspect.

SES' vision with this system is to allow seaweed cultivation in deeper and more exposed waters, opening the way for large scale production which is necessary to make seaweed a viable source of energy. Furthermore, they can be placed in a co-use concept with other marine operations, such as oil and gas, offshore wind and offshore wave ventures.

Regarding the production of bivalves, the collaboration between Sintef and Statoil as part of the European-funded research project Mermaid (Innovative multipurpose offshore platforms: planning, design and operation) has led to the design of 2 a possible exploitation models where salmon, mussels and seaweeds are grown together in a windmill park in the North Sea and Atlantic Ocean, respectively.

The North Sea model (southern North Sea at $40 \mathrm{~m}$ water depth and $100 \mathrm{~km}$ off from the coast line) estimates the electricity annual production to be $3300 \mathrm{GW} \mathrm{h}^{-1}$, at an annual average wind speed of $9.5 \mathrm{~m} \mathrm{~s}^{-1}$, based on $10 \mathrm{MW}$ WTS power production characteristics (Fig. 2.8). The annual salmon production is estimated at $60,000-70,000 \mathrm{t}$ based on a fish production of $20 \mathrm{~kg} \mathrm{~m}^{-3}$ (maximum $25 \mathrm{~kg} \mathrm{~m}^{-3}$ ) and a fish survival of $88-95 \%$. In financial terms, the salmon production would yield a total of 240-280 million $€$ at $4 € \mathrm{~kg}^{-1}$, which accounts for $50-60 \%$ of the annual electricity yield. In addition, the production of blue mussels and seaweed (e.g. sugar kelp) is estimated to reach 20,000-30,000 and 160,000-180,000 t respectively, representing roughly $20-30$ and $160-210$ million $€$, respectively (at $1 € \mathrm{~kg}^{-1}$ for both mussels and seaweed) (He et al. 2015). 


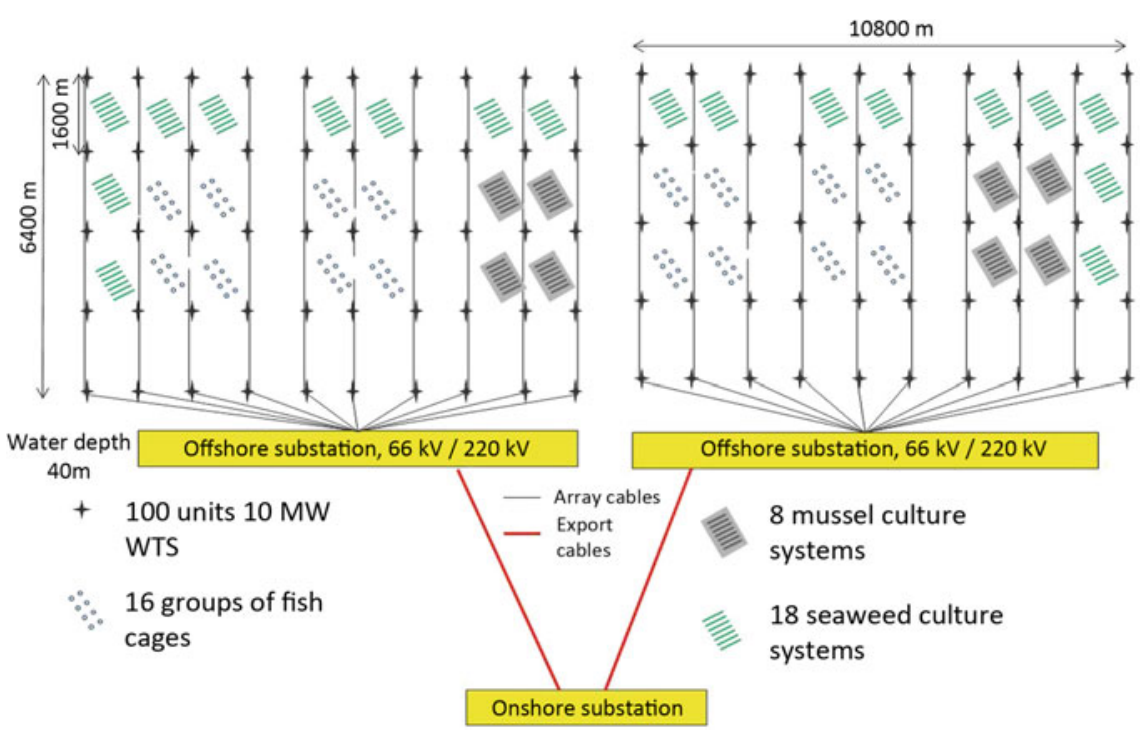

Fig. 2.8 Sintef-Statoil IMTA design for the North Sea (He et al. 2015)

\subsubsection{Denmark}

In Denmark, a feasibility study was carried out to look into mussel production on longlines in the windmill park Nysted. The park contains 7 windmills and measures $24 \mathrm{~km}$ (Christensen et al. 2009 in Verhaeghe et al. 2011). To our knowledge, no mussel production is taking place at the moment.

\subsubsection{The Netherlands}

For the production of fish and animal feed, as well as biofuels and energy, one of the first trials to farm seaweeds off the coast within a wind farm site was conducted by Ecofys and Hortimare in 2012. The system (Fig. 2.9a-h) that covers $400 \mathrm{~m}^{2}$ $(20 \mathrm{~m} \times 20 \mathrm{~m})$ consists of a set of steel cables, submerged $2 \mathrm{~m}$ below the sea surface and held by anchors and floating buoys. In between, horizontal nets $(10 \mathrm{~m} \times 10 \mathrm{~m})$, seeded with laminarian sporophytes, were suspended between those cables. In the plans was to test if the design is suitable for seaweed cultivation in offshore wind farms in the North Sea.

Bartelings et al. (2014) carried out a desk study to look into the possibilities to combine offshore aquaculture in windmill parks on the Dutch Continental Plateau. The study concluded that mussel culture and mussel seed culture on longlines are the most promising options within the Dutch context. It could potentially lead to a reduction of $40 \%$ of the total cost per MWh and the Dutch mussel sector would be 

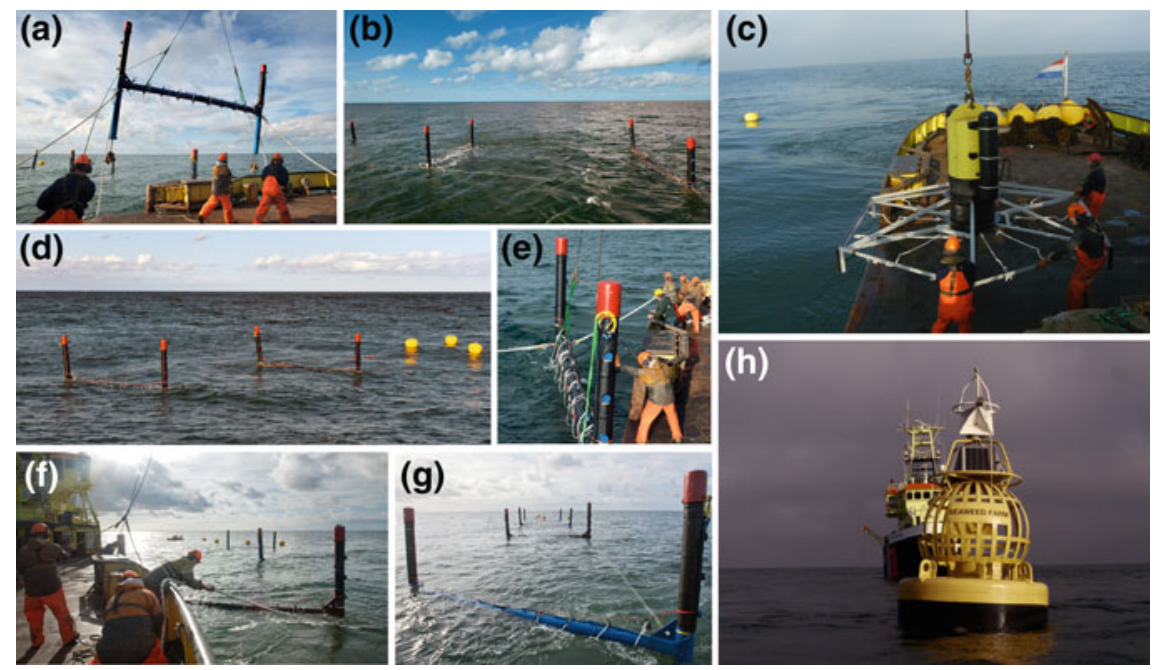

Fig. 2.9 Installation of the innovative H-frame seaweed farm offshore off Texel (Patent No. P94437EP00) as well as a seaweed test module. a Launching of the installation in October 2012 with RV Terschelling; b H-frame after launching, total length 120, 10 m wide; c launches of a test module $15 \mathrm{~km}$ out from coast Texel; $\mathbf{d}$ mooring by 2 anchors at both ends, 4 yellow buoys kept the mooring points floating; e work at the mooring in connection with the $\mathrm{H}$-frame during deployment; $\mathbf{f}$ installation work; $\mathbf{g}$ side view on the entire installation; $\mathbf{h}$ work offshore completed at the test farm of Noordzeeboerderij off Texel. Images $(\mathbf{a}, \mathbf{b}, \mathbf{d}-\mathbf{g})$ modified after Hortimare (2016), images $\mathbf{c}$ and $\mathbf{h}$ by Schuttelaar and Partners, other images are provided by Hortimare (2016)

offered a new market opportunities of $100,000 \mathrm{t}$. That is twice the current production. Fish culture in cages was considered impossible by the authors because of the shallow depth and no opinion was formulated towards the production of seaweeds. Lagerveld et al. (2014) also simulated the feasibility of combining an offshore wind farm with an offshore mussel farm in the Dutch North Sea, assuming certain synergies between the two activities.

As a result, Stichting Noordzeeboerderij (the North Sea Farm) is committed to develop a mass cultivation of seaweeds in the Dutch North Sea. In June 2015, Hortimare successfully executed a small scale test on the Dutch North Sea, $10 \mathrm{~km}$ North-East from the Island of Texel. This test site includes brown macroalgae, such as Saccharina latissima as well as Laminaria digitata. The test farm for S. latissima off Texel has a size of one $\mathrm{km}^{2}$, the $L$. digitata farm at the location called Proefboerderij is slightly smaller. Another test site is planned a few kilometers off the coast from Scheveningen (The Hague).

The planned construction of the new windmill park in Borsele (capacity of 1050-2100 MW, $22 \mathrm{~km}$ offshore of the Province of Zeeland, with a depth between 10 and $40 \mathrm{~m}$ ), that will start in the second half of 2016 has led to strong discussions about offshore aquaculture possibilites in the park. Van den Burg et al. (2016) report that aquaculture activities are not included in the tender and no specific 
advantage will be granted to the candidates who will include that option in their proposal. Four major advantages of culturing seaweed in the windmill park of Borsele have been identified: uptake of nutrients and reduction of eutrophication, attenuation of waves and hence less erosion of the windmill foundations, contribution to fish resources, and increased regional support through job creation.

\subsubsection{France}

In France, longline systems are used offshore along the Mediterranean and the Atlantic coasts. The Mediterranean farms have been in use since the late 1970s and are all fully submerged and produce up to $10,000 \mathrm{t} / \mathrm{year}$, although this has decreased in recent years due to predation and water quality. The techniques and equipment are fully described by Danioux et al. (2000). Offshore long lines have been used since the mid-nineties on the Atlantic coast and the coast of Charentais, Pertuis Breton and Pertuis Antioch. It is believed that there are several hundred lines in this region. Production is around $5000 \mathrm{t}$ from these offshore long lines. Expansion will depend on access to new space and improvement in techniques (Ögmundarson et al. 2011).

The project "WINSEAFUEL" was funded by the French National Research Agency and was one of the first French projects with an offshore multi-use aspect (Lasserre and Delgenès 2012). The aim of the project was to produce biomethane and bioproducts from macroalgae cultivated in the open sea next to offshore wind farm facilities (Langlois et al. 2012). A life cycle assessment for the production of biogas from offshore-cultivated macroalgal feedstock in a European framework was carried out, as well as production optimization from hatchery phase to offshore (Marfaing 2014).

In the North of France, at the border with Belgium, mussels are being produced in Dunkerque (North Sea) using the longline system. Ropes and anchors are made extra strong to cope with the local environmental conditions. The project started in 2006 and obtained its first good results in 2009. An annual production of $1000 \mathrm{t}$ is obtained nowadays. They are produced and commercialized by the fishermen's cooperative "Cooperative maritime de Dunkerque" as "Les Moules de Dunkerque" or "Les Moules du Banc de Flandre".

\subsubsection{United Kingdom}

In 2014, Kames Fish Farming Ltd. installed two offshore seaweed longline trials for research commissioned by the Bangor University's School of Ocean Science and the Scottish Association of Marine Science (SAMS), respectively (KFM 2014). The design consists of a small submerged rope grid supported on foam filled cushion buoys and oceanic mussel headline floats. The location of the first longline at 
Conwy Bay north of the Menai Straits is exposed to a high wave regime combined with a high tidal level accompanied with strong current velocities. The second longline was moored north of Oban (Argyll) Lynn of Lorne at Port a Bhuiltin.

Mussel bottom culture (Deepdock Ltd.) was tested in the windmill park of North Hoyle OWF (Wales) in 2010. The windmill park contains 30 monopiles and the depth was $10 \mathrm{~m}$ at low tide. The mussels grew well, but unexplainable mortality occurred at harvest. To our knowledge, no offshore mytiliculture is going on at the moment.

The Kentish Flats offshore wind farm about $10 \mathrm{~km}$ off the coast of Kent provides a permit to the fishing community to access the wind farm area for trawling of bivalves as well as for passive fishing strategies (Brown and May 2016). Studies had been undertaking with regard to various potential impacts on commercial fishing including the impacts of loss of fishing area resulting from offshore wind farm installations for environmental impact assessments supporting planning applications, compensation modelling and preparation of safety strategies. Mussels were caught at spat size and used for on-bottom cultivation. Other wind farms, such as Gwynt y Môr, North Hoyle, Lynn and Inner Dowsing wind farms were used for natural stock relay and ranching projects (CEFAS 2014). No commercial enterprise is running to this day.

\subsubsection{Italy}

Offshore long line mussel production has been in place in the Adriatic for some years and plays an increasingly significant part of production (Danioux et al. (2000). Experiments were carried out in the central part of the Adriatic sea (Conero Promotory, Ancona province) in Italy to assess the potential to produce mussels ( $M$. galloprovincialis) and oysters (Crassostrea gigas) in submerged structures in combination with artificial reefs in locations where traditional shellfish farming in not possible (Bombace et al. 2000; Fabi and Spagnolo 2001) (Fig. 2.10). The base units of the reef consist of concrete blocks of $8 \mathrm{~m}^{3}$ with holes of different diameters. The blocks are piled up into pyramids of 2 or 3 layers and layed down at depths of $10-20 \mathrm{~m}$. The distance between the pyramids is $15-50 \mathrm{~m}$. The units at the top are connected to each other with cables that support nets to collect the mussel seed or longlines systems. Concrete shellfish cages with dropper lines are placed between the pyramids.

The structures are seeded naturally with wild mussel seed and an average of $20-55 \mathrm{~kg} / \mathrm{m}^{2} /$ year is produced by the cages and the blocks. A reef of 116 pyramids and 48 cages produces $260 \mathrm{t}$ of mussels yearly on average. Based on this, the costs of a reef are paid back after 5 years. Thanks to the dynamic environment, the environmental impact is reduced to a minimum (Fabi et al. 2009). 
(a)

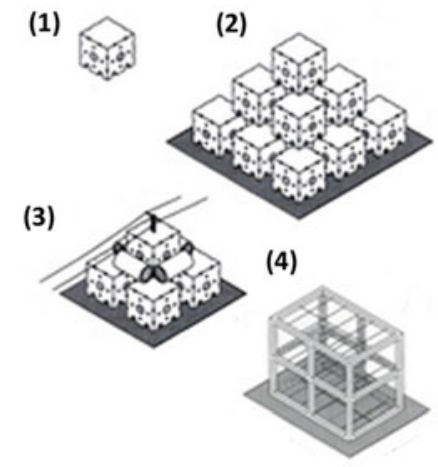

(c)

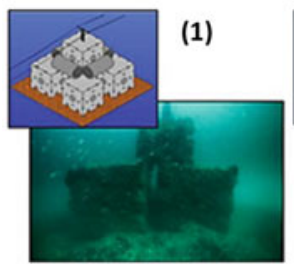

(b)

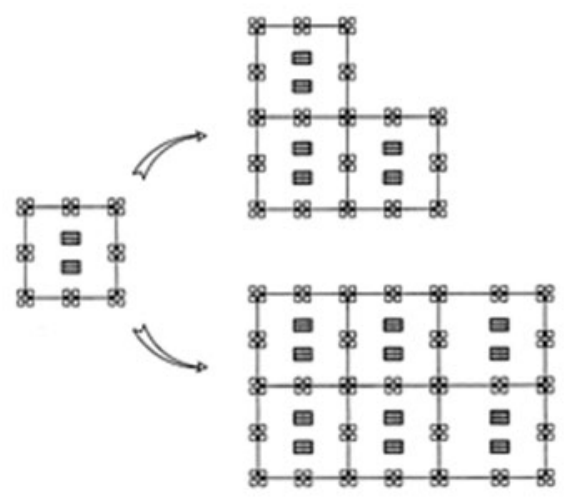

Fig. 2.10 (a-d): a examples of artificial reefs in the Adriatic sea (1), (2) pyramids, (3) connection for longlines, and (4) cages for shellfish (Bombace et al. 2000; Tassetti et al. 2015); b and d: layout of artifical reefs, in groups of 8 pyramids with 2 shellfish cages in the center (Bombace et al. 2000; Tassetti et al. 2015); c two-layer pyramids of concrete blocks (1) and concrete cages for mussel culture (2) (Tassetti et al. 2015)

\subsubsection{The United States}

In the USA, there have been discussions in the last years in co-locating aquaculture production together with offshore wind energy projects. One example to combine extractive species with offshore wind turbines was planned for the wind farm Cape Wind in Massachusetts (USA) (Lapointe 2013). Buck et al. (2011) prepared a first economic feasibility study on the production of seaweeds within this wind farm. Another attempt at multi-use of an offshore wind installation with mussels was conducted at Block Island Wind Farm, off the coast of Rhode Island (Voskamp 2010). Further, the Wind Technology Advancement Project (VOWTAP) conducted initial engineering, designing, and permitting for offshore wind energy installations off the coast of Virginia while taking aquaculture into account (Moura et al. 2011). They planned to collaborate with other local users by using the wind farm infrastructure to enhance the profitability of fisheries or aquaculture operations. However, the current expansion of natural gas production, with a concomitant decrease in gas 


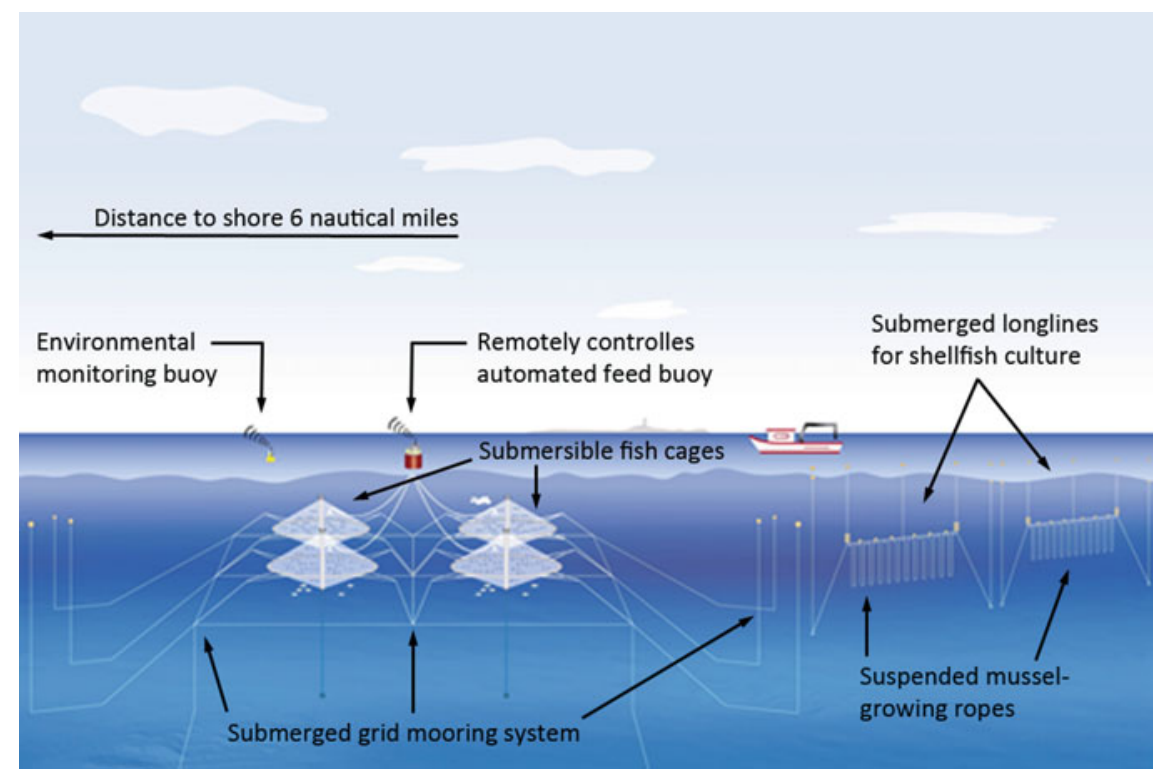

Fig. 2.11 Diagram of the University of New Hampshire's offshore installation depicting submerged fish cages, submerged shellfish longlines, automated feeding buoy and oceanographic instrumentation

prices, will likely have a significant dampening effect on the development of operational offshore wind energy projects or sites, which in turn would decrease the chance for multi-use aspects.

The University of New Hampshire (UNH) Open Ocean Aquaculture Project (http://amac.unh.edu) had a demonstration unit of 12 ha at $10 \mathrm{~km}$ off the coast in the Gulf of Maine that included finfish culture in submerged cages and shellfish (mussels and scallops on submerged longlines (Langan 2009) (Fig. 2.11).

Water depth is $52 \mathrm{~m}$ on average and the area is completely exposed (waves $>9 \mathrm{~m}$ high). The submerged longline system consists of a longline $(130 \mathrm{~m}$ long, $28 \mathrm{~mm}$ polysteel rope) with 3 floats ( 2 for the anchoring lines and one in the middle). Each anchoring line ( $28 \mathrm{~mm}$ polysteel rope) is kept in place with a weight of $4 \mathrm{t}$ and is connected directly to the anchor at an angle of $45^{\circ}$. The longline is kept at a depth of 10-12 m and carries mussel ropes that form loops of 7-12 m. In 1999, the first two submerged longlines were installed. They are still in place and tended by commercial operators though the anchors and the floats have been replaced several times. Three $\mathrm{km}$ to the south (Boars Head), there is a commercial production with 10 longlines (Verhaeghe et al. 2011).

More recently, UNH and New Hampshire Sea Grant have been developing IMTA platforms for marine fish, shellfish and seaweeds (Fig. 2.12a-b). IMTA is where the culture of a fed product (i.e. fish) is combined with the culture of extractive species that bio-mitigate nutrients from the farm and surrounding waters. 

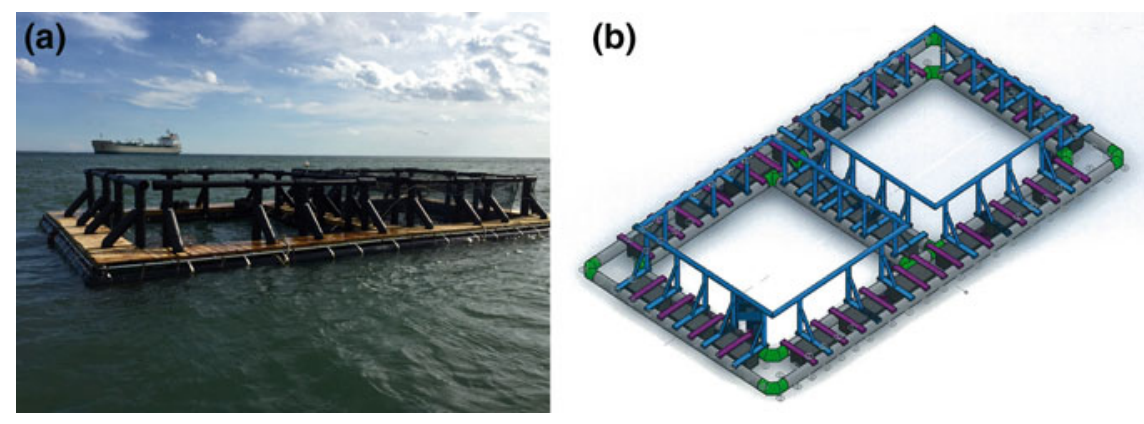

Fig. 2.12 (a-b): $\mathbf{a}-\mathbf{b}$ open ocean, integrated multi-trophic aquaculture raft being evaluated at the University of New Hampshire (a), first pilot scale set-up built after the model (b)

This creates product diversification, improves farm output, helps maintain a clean environment and is more socially acceptable. IMTA promotes economic and environmental sustainability by converting byproducts and uneaten feed from fed organisms into harvestable crops, thereby reducing eutrophication, and increasing economic diversification (Neori et al. 2004; Troell et al. 2003). IMTA has been investigated extensively in Atlantic Canada with salmon, blue mussels and kelps (Chopin et al. 2004, 2013; Ridler et al. 2006, 2007; Robinson et al. 2007).

The University has been engaging commercial fishermen on small-scale, IMTA as a means to diversify their income. By integrating the production of steelhead trout (Oncorhynchus mykiss), blue mussels (Mytilus edulis) and sugar kelp (Saccharina latissima) on a floating platform, fishermen have been able to grow and sell new sources of seafood (Fig. 2.12a-b). The IMTA model was initially adopted due to concerns by the United States Environmental Protection Agency of nitrogen inputs from fish feed in coastal areas that were already nitrogen impaired. Working with state and federal agencies, a nitrogen mass balance model was derived and a IMTA demonstration project was launched in 2012 (Chambers 2013).

The project sourced rainbow trout (known as steelhead in the ocean) from a local hatchery and stocked them diretly into seawater cages at $250 \mathrm{~g}$. New Zealand fuzzy rope was suspended around the cage perimeter to collect mussel spat. The fuzzy rope, made from loops of polyester line, provides abundant surface area for mussel settlement. Mussels typically spawn twice a year in the Gulf of Maine and adhere to bottom substrate and materials in the water column (Langan and Horton 2005). Sugar kelp is endemic to New England waters and naturally settles on subsurface substrate. Kelp sorus tissue (sporophyte) was collected from mature kelp blades growing on the seacages and spawned in captivity. With the help of Ocean Approved in Portland, ME (http://www.oceanapproved.com/) and Maine Sea Grant, kelp spores were successfully spawned onto twines that were later seeded onto vertical and horizontal growout lines at the cage site.

The UNH IMTA project demonstrated that nitrogen extraction by mussels $(2.0 \%$ tissue and shell), kelp (2.4\%), and trout (40\% at harvest) can exceed nitrogen input from trout production. With a $4: 1$ ratio, $4 \mathrm{t}$ of mussels/kelp to $1 \mathrm{t}$ of trout, more 
nitrogen can be extracted from the environment then inputs from feed thus having a net ecosystem benefit (Chambers 2013). Per these results, UNH was funded to design, construct and evaluate a robust, open ocean raft that is currently in the field.

This information has aided regulatory agencies in their decision making for permitting aquaculture. In addition, IMTA has created new sources of sustainable, local seafood and employment, helping fishermen diversify into seafood production while continuing to fish.

\subsubsection{The Republic of Korea}

Following the South-west offshore wind farm development plan, the construction of the first large scale offshore wind farm in the Republic of Korea in combination with seaweeds and bivalves started in 2016 (Figs. 2.13a-d and 2.14a-b). The co-location concept was suggested to the local communities in 2013 and was recently accepted. The major issue of co-using was the local acceptance by stakeholders, such as fisheries, local officials and the fisheries cooperative union. The multi-use concept was inspired by the shellfish and seaweed cultivation trials in Germany (North Sea) and Wales (North Hoyle and Gwynt y Môr). The objective of this project is, on one hand, the development of technology for co-locating fisheries and aquaculture with offshore wind farm, and, on the other hand, the multi-use concept which should improve the social acceptance of offshore wind farms. The first trials include IMTA systems that combine fish, sea cucumber, oysters and seaweeds (KEPCO and KIOST 2016).

Provincial governments have been developing offshore seaweed cultivation technologies. The target species for these offshore systems included, besides Porphyra, the species Saccharina and Undaria. The Aquatic Biomass Research Center (ABRC) carried out an offshore seaweed aquaculture project to produce seaweed biomass for biofuels (Chung et al. 2015). The objectives of this study were (1) to select appropriate seaweed species and to develop seed planting techniques for high density mass production, (2) to develop a Tension-Leg Platform (TLP) type seaweed cultivation system, and (3) to develop automatic out planting and harvesting systems. The TLP system provides a stable platform for seaweed cultivation even in the offshore environment. During phase I (2010-2013), a brown seaweed, Saccharina japonica, was successfully cultured on the TLP system near Geumil-do Island, Wando, Jeollanamdo. This TLP system is now installed near Cheongsan Island, between Wando and Jeju Island, growing several species, including Saccharina japonica, Ecklonia cava, E. stolonifera, Sargassum horneri, Myagropsis myagroides, and some others. The cost for a TLP system is estimated at $\$ 500,000$ for a 1 ha seaweed farm. Although this study showed potential to grow seaweeds in the offshore environment using the TLP system, limiting high production costs are the most challenging part. 

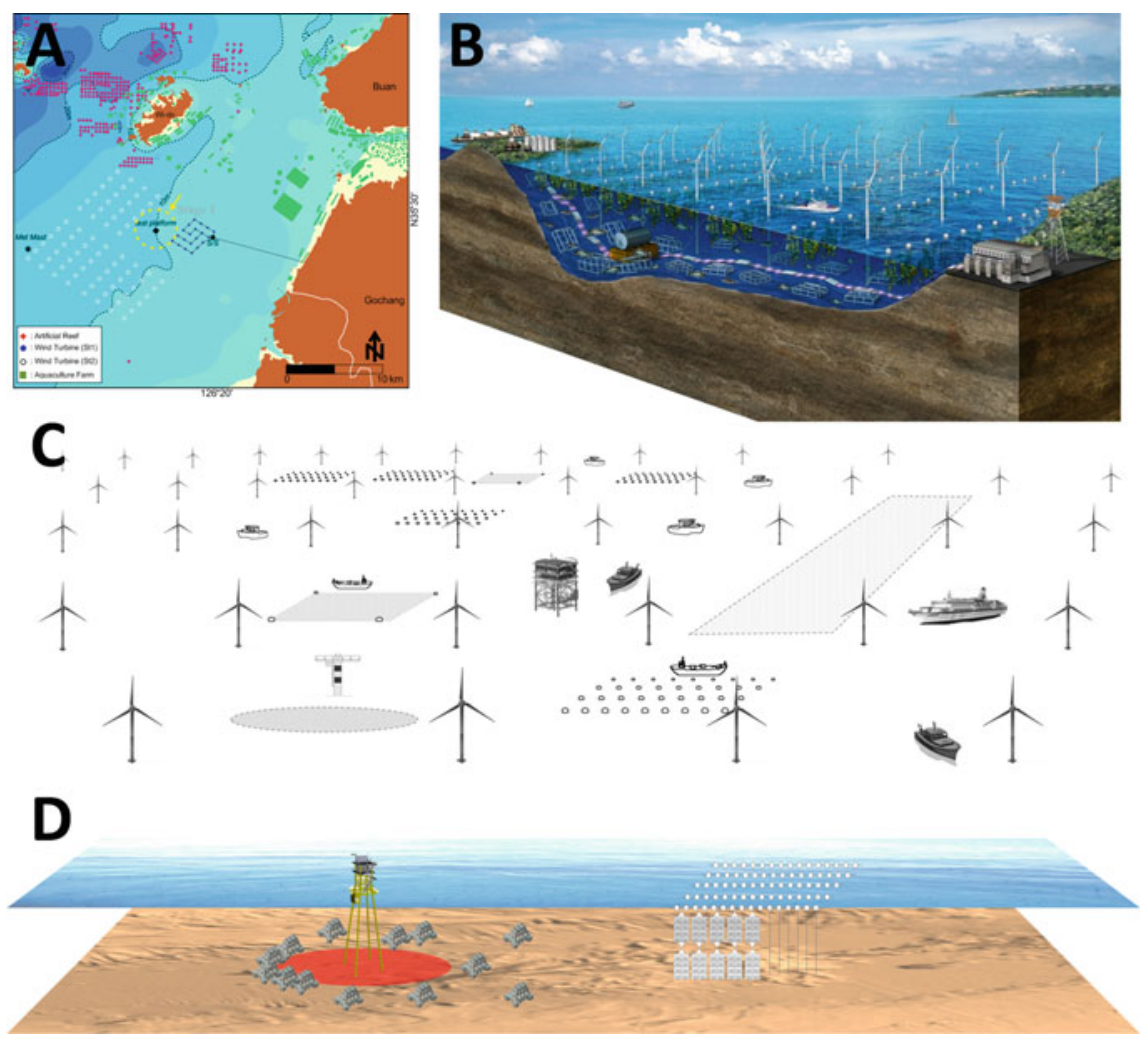

Fig. 2.13 (a-d): a co-location area for aquaculture within offshore wind farms off the coast of southern-east South-Korea; b drawing of the multi-use concept at the wind farm site shown in a profile view; c complete wind farm-aquaculture site for the first development stage; $\mathbf{d}$ wind farm foundation with artificial reefs and aquaculture installations in its vicinity. Modified after KEPCO and KIOST (2016)

\subsubsection{China}

Sea ranching as a commercial activity is mainly developed in China and Japan and can also be deployed in offshore areas. In China, there is the example of Zhangzidao Fishery Group Co. Ltd. The farm has a size of 40,000 ha of which 26,500 ha are used for the culture of pectinidae, sea urchin, abalone, and the sea cucumber Apostichopus japonicus. In 2005, the site produced 28,000 t of product with a value of US\$ 60 million. It is located near the Zhangzidao islands, north of the Yellow Sea, 40 miles away from the continent of Liaoning Province. Shellfish, macroalgae, crustaceae and echiniderms are grown at depths of 1-40 $\mathrm{m}$ in an area that is characterized by strong currents (max. $100 \mathrm{~cm} \mathrm{~s}^{-1}$ ).

On the other hand, suspended culture in open sea in China is practiced in Sungo (Sanggou) Bay (13,000 ha in total), east of Shandong Peninsula and is one of the 

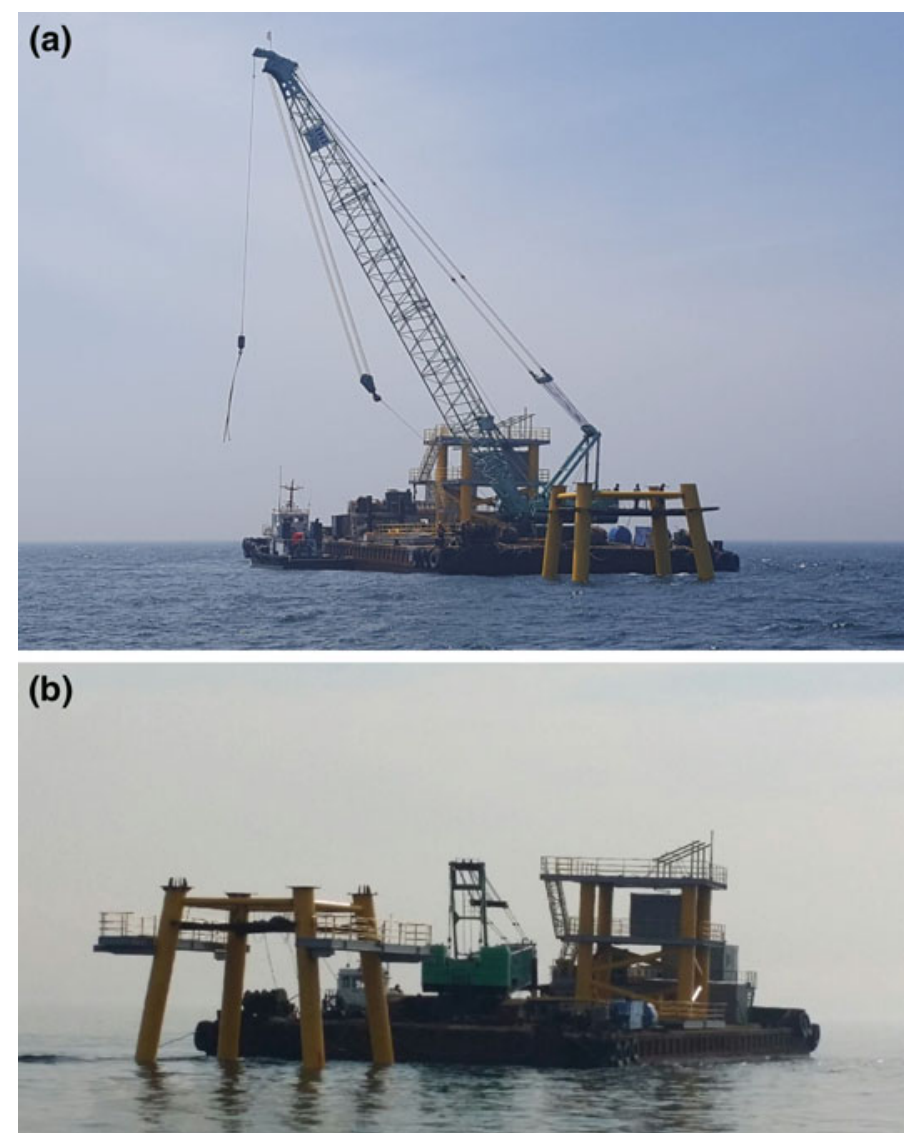

Fig. 2.14 (a-b): Deployment of the first wind farm foundation at the co-location wind farm project in the south-west of South Korea. a Foundation during mooring procedure; $\mathbf{b}$ preparation of the foundation for potential multi-uses. Modified after KEPCO and KIOST (2016)

most important mariculture regions for the scallop Chlamys farreri and the kelp Saccharina japonica in northern China (Fig. 2.15). The abalone H. discus hannai is also cultured there, and to a lesser degree the blue mussel M. edulis. The bay stretches $8 \mathrm{~km}$ from the coast, has a depth of $20-30 \mathrm{~m}$ and has currents up to $60 \mathrm{~cm} \mathrm{~s}^{-1}$. It has been estimated that dissolved nitrogen excreted by scallops in the Bay ( 2 billion individuals) amounts to $284 \mathrm{t}$ during a kelp culturing period. Similarly, the inorganic nitrogen excretion by mussels in the Bay $(0.27$ billion individuals) amounts to more than $11 \mathrm{t}$. Together with the excretion of other fouling animals such as sea squirt and oyster, the total inorganic nitrogen excretion of cultivated and fouling animals in the Bay amounts to more than $300 \mathrm{t}$. Twenty thousand tons of dried kelps can be produced annually through uptake of inorganic nitrogen from the Bay (Troell et al. 2009) (Fig. 2.15). 
(a)

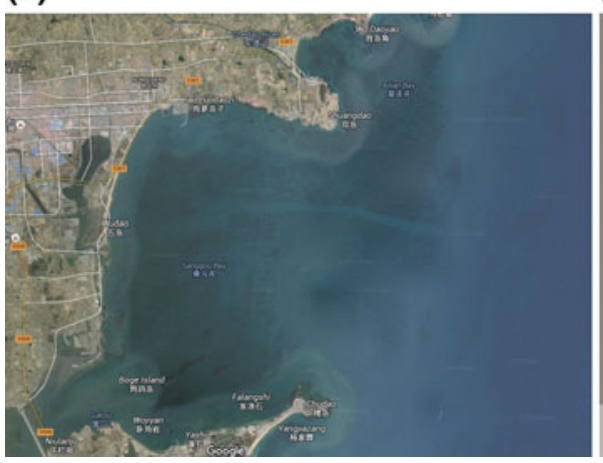

(b)

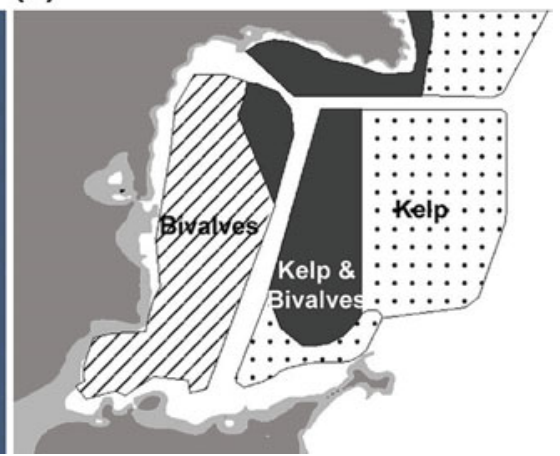

Fig. 2.15 a-b: a map of Sanggou Bay including the aquaculture site (Google Earth 2016); b drawing of the aquaculture area after site selection (Nunes et al. 2003)

The aquaculture cages shown in Fig. 2.16a-b have been proposed to co-use the space within offshore wind farms under open sea conditions. These cages are planned to be used in an IMTA mode with seaweed and bivalves as well as sea cucumbers. The co-location of aquaculture (small scale) will provide insights into the real barriers and risks encountered. The operational experience gained will encourage the stakeholders' interests in the development of commercial co-location.

Using offshore wind technology has the potential to help accelerate the movement of aquaculture to open water sites in China where the water quality is better. Combining both offshore wind farm with aquaculture meets the challenge of both the production of clean energy and high quality seafood while maintaining minimum environmental impact.

More than 50 experts from energy, vessels and fishery research groups and industries gathered at Jiangsu University of Science and Technology, China, to discuss: Going offshore: Combining offshore renewable energy and high-quality seafood production. The plan was to set-up a center for offshore aquaculture and renewable energy. The work plan for the center for combining offshore renewable energy and aquaculture have been proposed and discussed.

Chinese energy companies presented the energy technology development map including 44 offshore wind farms in China. The fishery research institute and university presented the Chinese aquaculture farms and the challenges.

\subsection{Ecosystem Services}

Most studies on macroalgae from temperate regions used as biofilters in IMTA focus on Saccharina latissima, Alaria esculenta, Ulva spp., Gracilaria spp. and Pyropia/Porphyra, which are well-established aquaculture species and whose nutrient uptake abilities are high compared to most other seaweeds (e.g. Chopin 

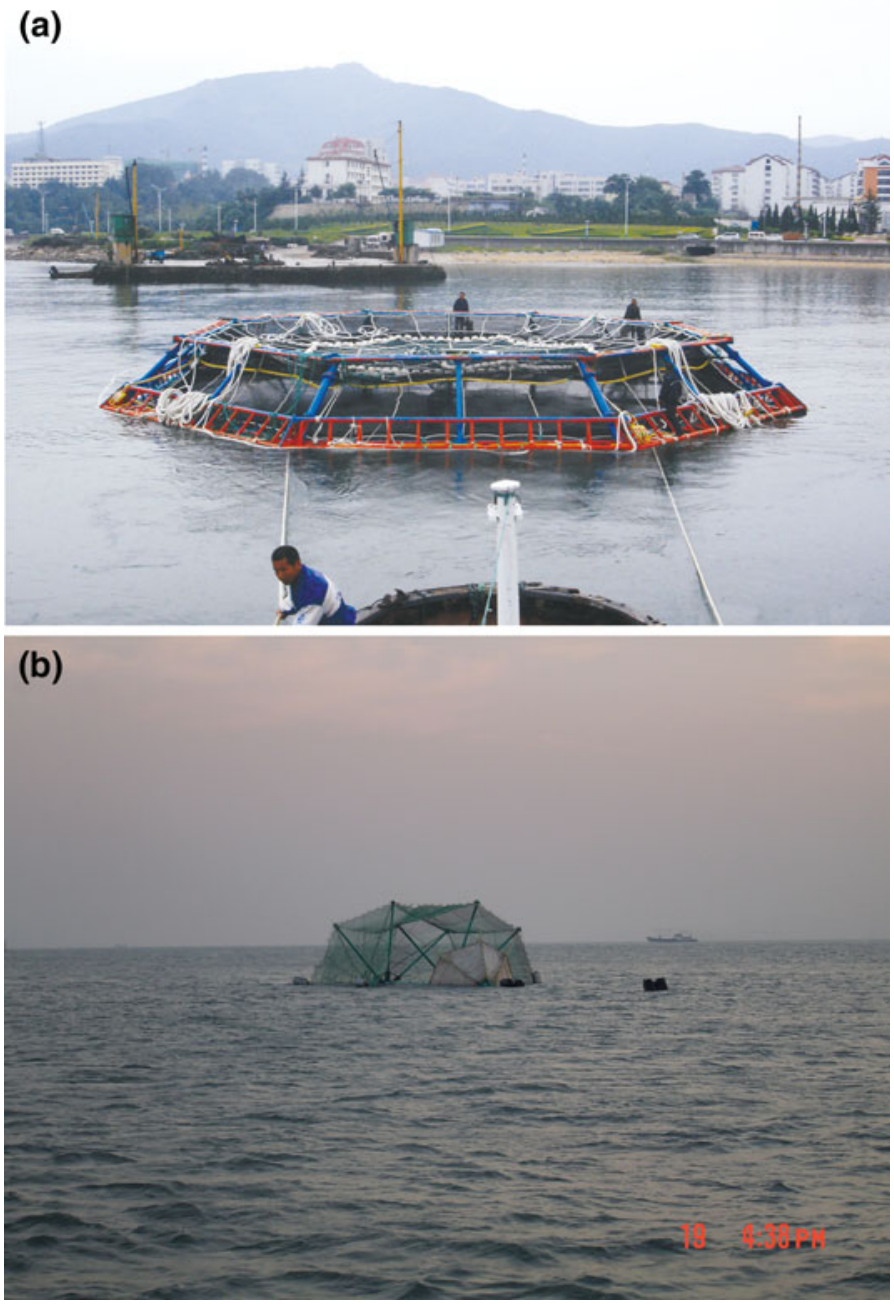

Fig. 2.16 a-b: proposed aquaculture cages for open sea conditions in combination with wind farm foundadtions. These are planned to be used in an IMTA mode

et al. 2004; Kang et al. 2014; Martinez-Aragon et al. 2002; Neori et al. 2000, 2004; Msuya and Neori 2008; Abreu et al. 2013; Sutherland et al. 2011). However, in the case of eco-intensification of offshore aquaculture operations, the macroalgae species additionally needs to be robust enough to withstand a high energy environment (Buck and Buchholz 2005). First attempts to use Saccharina latissima as well as Palmaria palmata within offshore IMTA systems was investigated by Grote (2016). First attempts to calculate nutrient budgets of Saccharina latissima and Palmaria palmata for the use as offshore IMTA candidate was investigated by Grote (2016) as well as Grote and Buck (2017). 
Recently, Kim et al. (2014a, 2015a) cultivated Gracilaria tikvahiae and Saccharina latissima in open water nutrient bioextraction farms in Long Island Sound (LIS) and the Bronx River Estuary (BRE), and evaluated the nutrient bioextraction performance in urbanized estuaries. They estimated that the biomass yields of $G$. tikvahiae and $S$. latissima could be up to 21 and 62 metric tons fresh weight per hectare, respectively. The potential nitrogen removal could exceed $320 \mathrm{~kg} \mathrm{~N} \mathrm{ha}{ }^{-1}$ year $^{-1}$ from LIS (280 kg ha ${ }^{-1}$ from Saccharina and $40 \mathrm{~kg} \mathrm{ha}^{-1}$ from Gracilaria) and $430 \mathrm{~kg} \mathrm{~N}^{-1}$ year $^{-1}$ from the BRE site $\left(280 \mathrm{~kg} \mathrm{ha}^{-1}\right.$ from Saccharina and $150 \mathrm{~kg} \mathrm{ha}^{-1}$ from Gracilaria).

Seaweed is also an important $\mathrm{CO}_{2}$ sink and the duration of net $\mathrm{CO}_{2}$ removal can be extended if the biomass is used in environmentally friendly ways (Chung et al. 2013). Kim et al. (2014a, 2015a) estimated that Gracilaria and Saccharina could sequester up to 300 (LIS) and $727 \mathrm{~kg} \mathrm{Cha}^{-1}$ (BRE), and 1800 (LIS) and $1350 \mathrm{~kg} \mathrm{C} \mathrm{ha}{ }^{-1}$ (BRE), respectively. Together, over $2000 \mathrm{~kg} \mathrm{C} \mathrm{ha}^{-1}$ could be removed by alternating these two species at the seaweed farm sites. An economic value of nutrient bioextraction was estimated. Considering the most recent nutrient credit values in the USA for these two elements (US $\$ 12.37 \mathrm{~kg}^{-1} \mathrm{~N}$, US \$6.00-US $\$ 60.00 \mathrm{mt}^{-1} \mathrm{C}$ (as $\mathrm{CO}_{2}$ ), Stephenson and Shabman 2011; CDP 2013; CT DEEP 2014; Tedesco et al. 2014), the potential economic values of $\mathrm{C}$ and $\mathrm{N}$ removal could exceed $\$ 3000 \mathrm{ha}^{-1}$, which could be additional income for seaweed growers beyond the value of seaweed products, if seaweed aquaculture is incorporated in the Connecticut Nitrogen Credit Trading Program and a carbon-pricing scheme (CDP 2013).

Considering the global seaweed production and tissue carbon and nitrogen contents for each species, total extractive nitrogen and carbon by seaweed aquaculture can be estimated. Considering a 10:1 DW:FW ratio and average values of nitrogen (Pyropia/Porphyra: 5.5\%, Gracilaria: 3.0\%, Kappaphycus/Eucheuma: 1.7\%, kelp: $2.0 \%$ and Sargassum: 4.1\%) and carbon (Pyropia/Porphyra: 38\%, Gracilaria: 28\%, Kappaphycus/Eucheuma: 29\%, kelp: 30\% and Sargassum: 34\%), the total nitrogen and carbon removal by these five major aquaculture groups is approximately 54 million $\mathrm{t}$ of nitrogen per year and 700 million $\mathrm{t}$ of carbon per year (equivalent to 2600 million $\mathrm{t}$ of $\mathrm{CO}_{2}$ ), respectively (Asare and Harlin 1983; Gerard 1997; Schaffelke and Klumpp 1998; Gevaert et al. 2001; Schaffelke 2001; Chung et al. 2002; Rawson et al. 2002; Sahoo and Ohno 2003; Dean and Hurd 2007; Kim et al. 2007, 2014a, 2015a; Buschmann et al. 2008; Abreu et al. 2009; Robertson-Andersson et al. 2009; Levine and Sahoo 2010; Broch et al. 2013). This is, in fact, a significant amount of carbon and nitrogen removal. In 2013, global nitrogen discharge to coastal waters and the open ocean via leaching and riverine transport was estimated to be up to 70 billion $t$ (Fowler et al. 2013). During the same period, carbon emissions due to fossil fuel use (and cement production) was 9.9 billion t. Seaweed aquaculture during the same period has removed approximately $0.13 \%$ of nitrogen discharge from leaching and riverine transport and $6.6 \%$ of carbon emission via fossil fuel use.

The extractive sequestration of nutrients by seaweeds provides ecosystem services that need to be recognized and valued appropriately (Chopin 2014). Much has 
been said about carbon sequestration and the development of carbon trading taxes. In coastal environments, mechanisms for the recovering of nitrogen and phosphorus should also be highlighted and accounted for in the form of nutrient trading credits (NTCs), a much more positive approach than taxing. If the composition of seaweeds can be averaged at around $0.35 \%$ nitrogen, $0.04 \%$ phosphorus and $3.00 \%$ carbon, and nutrient trading credits are valued at US $\$ 10-30 / \mathrm{kg}, \$ 4 / \mathrm{kg}$ and $\$ 30 / \mathrm{mt}$ for the respective compounds, the ecosystem services for nutrient biomitigation provided by the 23.8 million $t$ of worldwide annual seaweed aquaculture can be valued at between $\$ 892.5$ and $\$ 2.6$ billion - as much as $40 \%$ of its present commercial value. This significant value is, however, never noted in any budget sheet or business plan, as seaweeds are typically valued only for their biomass and food trading values. It is interesting to note that the above value for carbon is per tonne, whereas those for nitrogen and phosphorus are per kilogramme, a factor of 1000. Nobody seems to have picked up on that when looking at the sequestration of elements other than carbon. Moreover, having organisms able to accumulate phosphorus is becoming increasingly attractive, as this element will soon be in short supply.

The recognition of the ecosystem services provided by extractive species and the implementation of NTCs would give a fair price to extractive aquaculture (Chopin et al. 2010, 2012). They could be used as financial and regulatory incentive tools to encourage single-species aquaculturists to contemplate IMTA as a viable option to their current practices. Unfortunately, the Western world's animal-biased aquaculture sector and coastal managers and regulators often do not appreciate the ecosystemic roles of seaweeds and fail to take advantage of the environmental, economic and societal benefits provided by seaweeds and other extractive species, which have their full justification to be included in multi-use offshore platforms. Education and dissemination of the concept of ecosystem services will be key for their recognition by the general public, proper valuation by economic markets (Barbier 2013; Costanza et al. 2014), and appropriate use for the emergence of innovative aquaculture practices.

\subsection{Concluding Remarks and Outlook}

There is increasing concern about the negative consequences of intensive fish aquaculture and the need to remediate its consequences. The two strategies to meet the requirements for more space allotted to aquaculture have been and will continue to be the following: (1) offshore aquaculture, that to date seems very expensive and technically demanding, but due to ample space available, will allow considerable mass production and (2) the very promising but likewise complex IMTA approach.

A combined design of fish cages in the foundation of the turbines in addition to the extractive components of IMTA systems was first discussed at the World Aquaculture Conference in Korea in 2008 (McVey and Buck 2008). This led to a new project in the German Bight (Offshore Site-Selection, Buck and Krause 2012), 
where for the first time kelp species were tested in an IMTA approach offshore with partners from the offshore wind industry. Future multi-use development will require a great deal of coordination between offshore energy industries, the commercial offshore aquaculture sector, research institutions and international government agencies in order to be successful.

Both seed recruitment and growing and fattening phases are subject to changes in environmental conditions: mussel seed recruitment requires in most of the cases a natural settlement of the larvae on the collection systems, unlike, for instance, in the fish farming industry, where juveniles are bred in hatcheries. As for the feeding of the mussels, it also relies on naturally occurring phytoplankton present in the water column, as opposed to fish that are fed with manufactured fishmeal. In this sense mussel aquaculture depends highly on environmental determinants and their temporal variability. Chile that produces roughly 240,000 t of Mytilus chilensis per year experienced a crisis in 2009 when the phytoplankton concentrations decreased to such an extent that mussel growth came to a standstill (Serramalera 2015). Projected climate change poses multiple risks to mussel farming because of the increased frequency of extreme events that might lie outside the realm of present day experience (Serramalera 2015; Adger et al. 2005; Searle and Rovira 2008).

Natural variation in seed collection is inevitable. Environmental temperature for example has an impact on the egg quality and quantity produced by the female broodstock (Bayne et al. 1978) but also on the primary productivity which can have a major impact on larval development and survival. Predation on larvae also can vary significantly between years and is unpredictable. For example, in 2012 Chile found itself in a critical situation when spatfall in the mussel production areas was very poor for unexplained reasons (Carrasco et al. 2014).

Production of bivalves in hatcheries is a valid alternative and technically very feasible but it is not economically viable to produce hatchery seed of mussels in Europe currently because of the low market prices of the end-product. Production of triploid mussels may offer an interesting alternative, as is currently the case for the cupped oyster Crassostrea gigas, because this technique may also induce faster growth and lead to year-round supply (since the animals do not reproduce).

The IMTA multi-crop diversification approach (fish, seaweeds and invertebrates) could be an economic risk mitigation and management option to address pending climate change and coastal acidification impacts (Chopin 2015; Clements and Chopin 2016). Multi-species and multi-use systems could not only bring increased profitability per operation/cultivation unit, but also environmental sustainability and societal acceptability.

\section{References}

Abreu, M. H., Pereira, R., Yarish, C., Buschmann, A. H., \& Sousa-Pinto, I. (2011b). IMTA with Gracilaria vermiculophylla: Productivity and nutrient removal performance of the seaweed in a land-based pilot scale system. Aquaculture, 312, 77-87. 
Abreu, M. H., Pereira, R., Yarish, C., Buschmann, A. H., \& Sousa-Pinto, I. (2013). IMTA with Gracilaria vermiculophylla: Productivity and nutrient removal performance of the seaweed in a land-based pilot scale system. Aquaculture, 312, 77-87.

Abreu, M. H., Varela, D. A., Henriquez, L., Villarroel, A., Yarish, C., Sousa-Pinto, I., et al. (2009). Traditional vs. integrated multi-trophic aquaculture of Gracilaria chilensis C. J. Bird, J. McLachlan \& E. C. Oliveira: Productivity and physiological performance. Aquaculture, 293, 211-220.

ACE. (2015). ACE expands with seaweed site. Accessed November 6, 2015, at http://aceaqua.no/ en/2015/09/ace-expands-with-seaweed-site

Adger, W. N., Hughes, T. P., Folke, C., Carpenter, S. R., \& Rockström, J. (2005). Social-ecological resilience to coastal disasters. Science, 309, 1036-1039.

Asare, S. O., \& Harlin, M. M. (1983). Seasonal fluctuations in tissue nitrogen for five species of perennial macroalgae in Rhode Island Sound. Journal of Phycology, 19, 254-257.

Bakken, P. (2013). Seaweed to bio-fuels future direction. In International Seaweed Symposium, April 23, 2013, Bali (Indonesia).

Barbier, E. B. (2013). Valuing ecosystem services for coastal wetland protection and restoration: Progress and challenges. Resources, 2, 213-230.

Barrington, K., Chopin, T., \& Robinson, S. (2009). Integrated multi-trophic aquaculture (IMTA) in marine temperate waters. In D. Soto (Ed.), Integrated mariculture: A global review (pp $7-$ 46). FAO fisheries and aquaculture technical paper, No. 529. Rome: FAO.

Bartelings, H., Burg van den, S., Jak, R., Jansen, H., Klijnstra, J., Lagerveld, S., et al. (2014). Combining offshore wind energy and large-scale mussel farming: Background and technical, ecological and economic considerations. In S. Lagerveld, C. Rockmann \& M. Scholl (Eds.), Imares Wageningen UR (117 pp). Report C056/14.

Bayne, B. L., Holland, D. L., Moore, M. N., Lowe, D. M., \& Widdows, J. (1978). Further studies on the effects of stress in the adult on the eggs of Mytilus edulis. Journal of the Marine Biological Association of the United Kingdom, 58, 825-841.

Beveridge, M. (1987). Cage aquaculture (p. 351). Farnham, England: Fishing News Ltd.

Blouin, N. A., Brodie, J. A., Grossman, A. C., Xu, P., \& Brawley, S. H. (2011). Porphyra: A marine crop shaped by stress. Trends in Plant Science, 16, 29-37.

Bombace, G., Fabi, G., \& Fiorentini, L. (2000). Artificial reefs in the Adriatic Sea. In A. C. Jensen, K. J. Collins \& A. P. M. Lockwood (Eds.), Artificial reefs in European seas (pp. 31-63). Kluwer Academic Publishers.

Brenner, M., Broeg, K., Frickenhaus, S., Buck, B. H., \& Koehler, A. (2014). Multi-biomarker approach using the blue mussel (Mytilus edulis L.) to assess the quality of marine environments: Season and habitat-related impacts. Marine Environmental Research, 95, 1327.

Brenner, M., Buchholz, C., Heemken, O., Buck, B. H., \& Koehler, A. (2012). Health and growth performance of blue mussels (Mytilus edulis L.) from two different hanging cultivation sites in the German Bight: A nearshore-Offshore comparison. Aquaculture International, 20, 751778.

Brenner, M., Buck, B. H., \& Köhler, A. (2007). New concepts for the multi-use of offshore wind farms and high quality mussel cultivation. Global Aquaculture Advocate, 10, 79-81.

Broch, O. J., Ellingsen, I. H., Forbord, S., Wang, X., Volent, Z., Alver, M. O., et al. (2013). Modelling the cultivation and bioremediation potential of the kelp Saccharina latissima in close proximity to an exposed salmon farm in Norway. Aquaculture Environment Interactions, 4, 186-206.

Brown \& May (2016). Brown \& May Marine Ltd. Accessed May 18, 2016, at http://www. brownandmaymarine.com

Buchholz, C. M., Krause, G., \& Buck, B. H. (2012). Seaweed and man. In C. Wiencke \& K. Bischof (Eds.), Seaweed biology, ecological studies (pp. 471-493). Springer, Berlin.

Buck, B. H. (2002). Open Ocean Aquaculture und Offshore Windparks Eine Machbarkeitsstudie über die multifunktionale Nutzung von Offshore-Windparks und Offshore-Marikultur im Raum 
Nordsee. Reports on Polar and Marine Research, Alfred Wegener Institute for Polar and Marine Research, Bremerhaven, 412, 252 pp.

Buck, B. H. (2004). Farming in a high energy environment: Potentials and constraints of sustainable offshore aquaculture in the German Bight (North Sea), PhD Thesis, Alfred Wegener Institute for Polar and Marine Research Bremerhaven, 214 pp., University of Bremen.

Buck, B. H. (2007). Experimental trials on the feasibility of offshore seed production of the mussel Mytilus edulis in the German Bight: Installation, technical requirements and environmental conditions. Helgoland Marine Research, 61, 87-101.

Buck, B. H. (2017). Mytilid larval appearance and settlement at offshore wind farm sites in the German Bight - a trial to estimate multi-use potentials for bivalve seed collection and cultivation. Helgoland Mar Research.

Buck, B. H., \& Buchholz, C. M. (2004a). The offshore-ring: A new system design for the open ocean aquaculture of macroalgae. Journal of Applied Phycology, 16, 355-368.

Buck, B. H., \& Buchholz, C. M. (2004b). Support device for the cultivation of macro organisms in marine waters. Patent: PCT/DE2005/000234.

Buck, B. H., \& Buchholz, C. M. (2005). Response of offshore cultivated Laminaria saccharina to hydrodynamic forcing in the North Sea. Aquaculture, 250, 674-691.

Buck, B. H., \& Krause, G. (2012). Integration of aquaculture and renewable energy systems. In R. A. Meyers (Ed.), Encyclopaedia of sustainability science and technology (Vol. 1, pp. 511533). Springer Science+Business Media LLC (Chapter No. 180).

Buck, B. H., \& Krause, G. (2013). Short expertise on the potential combination of aquaculture with marine-based renewable energy systems. SeaKult-Sustainable Futures in the Marine Realm. Expertise für das WBGU-Hauptgutachten „Welt im Wandel: Menschheitserbe Meer“. Wissenschaftlicher Beirat der Bundesregierung Globale Umweltveränderungen (WBGU). 58 pp.

Buck, B. H., Ebeling, M., \& Griffin, R. (2011). Seaweed aquaculture as a co-use in an offshore wind farm-Feasibilities and constraints of economic viability for cape wind (Massachusetts). AWI-Report—Project No. USA 11/A01, 12 p.

Buck, B. H., Ebeling, M., \& Michler-Cieluch, T. (2010). Mussel cultivation as a co-use in offshore wind farms: Potentials and economic feasibility. Aquaculture Economics and Management, 14, 255-281.

Buck, B. H., Krause, G., \& Rosenthal, H. (2004). Extensive open ocean aquaculture development within wind farms in Germany: The prospect of offshore co-management and legal constraints. Ocean \& Coastal Management, 47(3-4), 95-122.

Buck, B. H., Walter, U., Rosenthal, H., \& Neudecker, T. (2006a). The development of Mollusc farming in Germany: Past, present and future. World Aquaculture Magazine, 6-11, 66-69.

Buck, B. H., Berg-Pollack, A., Assheuer, J., Zielinski, O., \& Kassen, D. (2006b). Technical realization of extensive aquaculture constructions in offshore wind farms: Consideration of the mechanical loads. In Proceedings of the 25th international conference on offshore mechanics and arctic engineering, OMAE 2006: Presented at the 25th International conference on offshore mechanics and arctic engineering, 4-9 June 2006, Hamburg, Germany/sponsored by Ocean, offshore, and arctic engineering, ASME. New York, NY: American Society of Mechanical Engineers, pp 1-7.

Buschmann, A. H., López, D., \& González, M. (2000). Cultivo integrado de moluscos y macroalgas en líneas flotantes y en estanques. In F. M. Faranda, R. Albertini, J.A. Correa (Eds.), Manejo Sustentable de los Recursos Marinos Bentónicos en Chile Centro-Sur: Segundo Informe de Avance. Pontificia Universidad Católica de Chile, Santiago, 7-16.

Buschmann, A. H., Varela, D. A., Hernández-González, M. C., \& Huovinen, P. (2008). Opportunities and challenges for the development of an integrated seaweed-based aquaculture activity in Chile: Determining the physiological capabilities of Macrocystis and Gracilaria as biofilters. Journal of Applied Phycology, 20, 571-577.

Carlberg, L. K., \& Christensen, E. D. (2015). Go offshore-Combining food and energy production. DTU Mechanical Engineering, Technical University of Denmark. 48 pp. 
Carrasco, A., Astorga, M., Cisterna, A., Arias, A., Espinoza, V., \& Uriarte, I. (2014). Pre-feasibility study for the installation of a Chilean mussel Mytilus chilensis (Hupé, 1854) seed hatchery in the lakes region, Chiles. Fisheries and Aquaculture Journal, 5, 102.

CDP. (2013). Use of internal carbon price by companies as incentive and strategic planning tool: A review of findings from CDP 2013 disclosure. CDP North America. New York. Retrieved October 23, 2015, from https://www.cdp.net/CDPResults/companies-carbon-pricing-2013.pdf

CEFAS. (2014). Centre for environment, fisheries and aquaculture science. Project partner meeting for the EFF project: Shellfish aquaculture in welsh offshore wind farms. Fishmongers' Hall, London, May 22, 2013. Access via Aquafishsolutions, Accessed May 18, 2016 at www. aquafishsolutions.com

Chambers, M. D. (2013). Integrated multi-trophic aquaculture of steelhead, Blue Mussels and Sugar Kelp, Ph.D. dissertation. Department of Biological Sciences, University of New Hampshire, Durham, NH.

Chen, T. T., Lin, C. M., Chen, M. J., Lo, J. H., Chiou, P. P., Gong, H. Y., et al. (2014). Principles and application of transgenic technology in marine organisms. In S. K. Kim (Ed.), Handbook of marine biotechnology. Berlin: Springer.

Chopin, T. (2006). Integrated multi-trophic aquaculture. What it is and why you should care ... and don't confuse it with polyculture. Northern Aquaculture, 12, 4.

Chopin, T. (2014). Seaweeds: Top mariculture crop, ecosystem service provider. Global Aquaculture Advocate, 17, 54-56.

Chopin, T. (2015). Marine aquaculture in Canada: well-established monocultures of finfish and shellfish and an emerging Integrated Multi-Trophic Aquaculture (IMTA) approach including seaweeds, other invertebrates, and microbial com-munities. Fisheries, 40, 28-31.

Chopin, T., Buschmann, A. H., Halling, C., Troell, M., Kautsky, N., Neori, A., et al. (2001). Integrating seaweeds into marine aquaculture systems: A key toward sustainability. Journal of Phycology, 37, 975-986.

Chopin, T., Cooper, A., Reid, G., Cross, S., \& Moore, C. (2012). Open-water integrated multi-trophic aquaculture: Environmental biomitigation and economic diversification of fed aquaculture by extractive aquaculture. Reviews in Aquaculture, 4, 209-220.

Chopin, T., Neori, A., Buschmann, A., Pang, S., \& Sawhney, M. (2011). Diversification of the aquaculture sector. Seaweed cultivation, integrated multi-trophic aquaculture, integrated sequential biorefineries. Global Aquaculture Advocate, 14, 58-60.

Chopin, T., Robinson, S., Sawhney, M., Bastarache, S., Belyea, E., Shea, R., et al. (2004). The AquaNet integrated multi-trophic aquaculture project: Rationale of the project and development of kelp cultivation as the inorganic extractive component of the system. Bulletin-Aquaculture Association of Canada, 104, 11-18.

Chopin, T., Robinson, S. M. C., Troell, M., Neori, A., Buschmann, A. H., \& Fang, J. (2008). Multitrophic integration for sustainable marine aquaculture. In S. E. Jørgensen \& B. D. Fath (Eds.), Ecological engineering. Vol. 3 of Encyclopedia of Ecology (Vol. 5, pp. 2463-2475). Oxford: Elsevier

Chopin, T., Robinson, S., Reid, G., \& Ridle, N. (2013). Prospects for Integrated Multi-Trophic Aquaculture (IMTA) in the open ocean. Bulletin of the Aquaculture Association of Canada,111 (2), 28-35.

Chopin, T., Troell, M., Reid, G. K., Knowler, D., Robinson, S. M. C., Neori, A., et al. (2010). Integrated multi-trophic aquaculture (IMTA) - A responsible practice providing diversified seafood products while rendering biomitigating services through its extractive components. In N. Franz \& C. C. Schmidt (Eds.), Proceedings of the Organisation for economic co-operation and development (OECD) workshop "Advancing the Aquaculture Agenda: Policies to Ensure a Sustainable Aquaculture Sector”, Paris, France, 15-16 April 2010: 195217 (p. 426). Paris: Organisation for Economic Co-operation and Development.

Chopin, T., Yarish, C., Wilkes, R., Belyea, E., Lu, S., \& Mathieson, A. (1999). Developing Porphyra/salmon integrated aquaculture for bioremediation and diversification of the aquaculture industry. Journal of Applied Phycology, 11, 463-472. 
Christensen, H. T., Christoffersen, M., Doler, P., Stenberg, C., \& Kristensen, P. S. (2009). Assessment of possibilities for line cultivation of mussels in Nysted Sea Wind Farm. Project report DTU Aqua.

Chung, I. K., Kang, Y. H., Yarish, C., Kraemer, G. P., \& Lee, J. (2002). Application of seaweed cultivation to the bioremediation of nutrient-rich effluent. Algae, 17, 187-194.

Chung, H., Kim, N. G., Choi, K. J., \& Woo, H. C. (2015). Novel ocean system for high density mass production of seaweed biomass in Korea. In 2015 World Congress on Advances in Structural Engineering and Mechanics (ASEM15). Retrieved November 15, 2015, from http:// www.i-asem.org/publication_conf/asem15/7.ICOSE15/1w/W1H.HChung.OSE.F1.pdf

Chung, I. K., Oak, J. H., Lee, J. A., Shin, J. A., Kim, J. G., \& Park, K.-S. (2013). Installing kelp forests/seaweed beds for mitigation and adaptation against global warming: Korean project overview. ICES Journal of Marine Science. doi:10.1093/icesjms/fss206

Clements, J., \& Chopin, T. (2016) Ocean acidification and marine aquaculture in North America: Potential impacts and mitigation strategies. Reviews in Aquaculture, 0, 1-16. doi:10.1111/raq. 12140

Connecticut Department of Energy and Environmental Protection (CT DEEP). (2014). Report of the Nitrogen credit advisory board for calendar year 2013 to the joint standing environment committee of the general assembly.

Corey, P., Kim, J. K., Duston, J., \& Garbary, D. J. (2014). Growth and nutrient uptake by Palmaria palmata (Palmariales, Rhodophyta) integrated with Atlantic halibut recirculating aquaculture. Algae, 29, 35-45.

Corey, P., Kim, J. K., Garbary, D. J., Prithiviraj, B., \& Duston, J. (2012). Bioremediation potential of Chondrus crispus (Basin Head) and Palmaria palmata: Effect of temperature and high nitrate on nutrient removal. Journal of Applied Phycology, 24, 441-448.

Cornish, M. L., \& Garbary, D. J. (2010). Antioxidants from macroalgae: Potential applications in human health and nutrition. Algae, 25, 155-171.

Costanza, R., d'Arge, R., de Groot, R., Farber, S., Grasso, M., Hannon, B., et al. (1997). The value of the world's ecosystem services and natural capital. Nature, 387:253-260.

Costanza, R., de Groot, R., Sutton, P., van der Ploeg, S., Anderson, S. J., Kubiszewski, I., et al. (2014). Changes in the global value of ecosystem services. Global Environmental Change, 26, $152-158$.

CRM. (2001). Wirtschaftliches und ökologisches Potential einer Laminarien-Farm in Deutschland (Economic and ecologic potentials of algae farming in Germany). Kiel (Germany): Coastal Research and Management.

Danioux, C., Bompais, X., Paquotte, P., \& Loste, C. (2000). Offshore mollusc production in the Mediterranean Basin. In J. Muir \& B. Basurco (Eds.), Mediterranean offshore mariculture (pp. 115-140). Zaragoza: CIHEAM (Options Méditerranéennes: Série B. Etudes et Recherches, no 30).

Dean, P. R., \& Hurd, C. L. (2007). Seasonal growth, erosion rates, and nitrogen and photosynthetic ecophysiology of Undaria pinnatifida (Heterokontophyta) in southern New Zealand. Journal of Phycology, 43, 1138-1148.

Delbare, D. (2001). Pesca-project: Hangmosselcultuur in Belgische kustwateren. Centrum voor landbouwkundig onderzoek-Gent, Departement Zeevisserij - afdeling Aquacultuur en Restocking. pp. 14

Dillehay, T. D., Ramrez, C., Pino, M., Collins, M. B., Rossen, J., \& Pino-Navarro, J. D. (2008). Monte Verde: Seaweed, food, medicine, and the peopling of South America. Science, 320, 784-786.

Dong, S., Fang, J., Jansen Henrice, M., \& Verreth, J. (2013). Review on integrated mariculture in China, including case studies on successful polyculture in coastal Chinese waters. Report, Asem Aquaculture Plaform, 7th framework programme.

Fabi, G., \& Spagnola, A. (2001). Artificial reefs and mariculture. In J. Coimbra (Ed.), Modern aquaculture in the coastal zone (pp. 91-98). IOS Press.

Fabi, G., Manoukian, S., \& Spagnolo, A. (2009). Impact of an open-sea suspended mussel culture on macrobenthic community (Western Adriatic Sea). Aquaculture, 289, 54-63. 
FAO. (2014). The state of world fisheries and aquaculture 2014. Rome: Food and Agriculture Organization. $223 \mathrm{pp}$.

FAO. (2016a). The state of world fisheries and aquaculture. Rome: Food and Agriculture Organization, FAO.

FAO. (2016b) Fisheries and aquaculture information and statistics branch. Food and Agriculture Organization: Accessed April 17, 2016.

Fowler, D., Coyle, M., Skiba, U., Sutton, M. A., Cape, J. N., Reis, S., et al. (2013). The global nitrogen cycle in the twenty-first century. Philosophical Transaction of the Royal Society B, $368,0130164$.

Gellenbeck, K. (2012). Utilization of algal materials for nutraceutical and cosmeceutical applications-What do manufacturers need to know? Journal of Applied Phycology, 24, 309-313.

Gerard, V. A. (1997). The role of nitrogen nutrition in high-temperature tolerance of kelp, Laminaria saccharina. Journal of Phycology, 33, 800-810.

Getchis, T. S., Rose, C. M., Carey, D., Kelly, S., Bellantuono, K., \& Francis, P. (2008). A guide to marine aquaculture permitting in Connecticut. Connecticut Sea Grant College Program. 140p.

Gevaert, F., Davoult, D., Creach, A., Kling, R., Janquin, M. A., Seuront, L., et al. (2001). Carbon and nitrogen content of Laminaria saccharina in the eastern English Channel: Biometrics and seasonal variations. Journal of the Marine Biological Association of the UK, 81, 727-734.

Google Earth. (2016). Map data@2016 imagery (C2016 CNES/Astrium. DigitalGlobe, Landsat: CNES/Spot Image.

Gosling, E. (2003). Bivalve Molluscs: Biology, ecology and culture (456 p). Fishing News Books Ltd.

Grote, B. (2016). Bioremediation of aquaculture wastewater: Evaluating the prospects of the red alga Palmaria palmata (Rhodophyta) for nitrogen uptake. Journal of Applied Phycology, 28, 3075-3082.

Grote, B., \& Buck, B. H. (2017). The IMTA-approach for nutrient balanced aquaculture: Evaluating the potential of turbot (Scophthalmus maximus) and dulse (Palmaria palmata) from onshore RAS to offshore wind farm environment. Aquaculture.

Guiry, M. D., \& Guiry, G. M. (2015). AlgaeBase. Galway: World-wide electronic publication, National University of Ireland. Accessed May 21, 2015 at http://www.algaebase.org

Handå, A. (2012). Cultivaton of mussels (Mytilus edulis): Feed requirements, storage and integration with salmon farming. Doctoral thesis Norwegian University of Science and Technology NTNU. Norway, $200 \mathrm{pp}$.

Handå, A., Ranheim, A., Olsen, A. J., Altin, D., Reitan, K. I., Olsen, Y., et al. (2012). Incorporation of salmon fish feed and feces components in mussels (Mytilus edulis): Implications for integrated multi-trophic aquaculture in cool-temperate North Atlantic waters. Aquaculture, 370-371, 40-53.

He, P., \& Yarish, C. (2006). The developmental regulation of mass cultures of free-living conchocelis for commercial net seeding of Porphyra leucosticta from Northeast America. Aquaculture, 257, 373-381.

He, W., Yttervik, R., Olsen, G. P., Ostvik, I., Jimenez, C., Impelluso, T., \& Schouten, J. (2015). A case study of multi-use platform: Aquaculture in offshore wind farms, Poster no 54, EWEA Offshore 2015 Copenhagen, March 10-12, 2015.

Horn, S. J., Aasen, I. M., \& Østgaard, K. (2000). Ethanol production from seaweed extract. Journal of Industrial Microbiology and Biotechnology, 25, 249-254.

Hortimare. (2016). Propagating seaweed for a sustainable future. Accessed online October 22, 2016, at http://www.hortimare.com/

Hou, J., \& Jin, Y. (2005). The healing power of chinese herbs and medicinal recipes. New York: Haworth Press Inc.

Hurd, C. L., Harrison, P. J., Bischof, K., \& Lobban, C. S. (2014). In Seaweed ecology and physiology (2nd ed., $552 \mathrm{pp}$ ). Cambridge University Press.

Hwang, E. K., Cho, Y. C., \& Sohn, C. H. (1998). Reuse of holdfasts in Hizikia cultivation. Korean Journal of Fisheries and Aquatic Sciences, 32, 112-116. 
Hwang, E. K., Gong, Y. G., Hwang, I. L., Park, E. J., \& Park, C. S. (2013). Cultivation of the two perennial brown algae Ecklonia cava and E. stolonifera for abalone feeds in Korea. Journal of Applied Phycology, 25, 825-829.

Hwang, E. K., Ha, D. S., Baek, J. M., Wee, M. Y., \& Park, C. S. (2006). Effects of pH and salinity on the cultivated brown alga Sargassum fulvellum and associated animals. Algae, 21, 317-321.

Hwang, E. K., Park, C. S., \& Baek, J. M. (2007). Artificial seed production and cultivation of the edible brown alga, Sargassum fulvellum (Turner) C. Agardh: developing a new species for seaweed cultivation in Korea. Journal of Applied Phycology, 18, 251-257.

Jansen, H. M. (2012). Bivalve nutrient cycling-nutrient turnover by suspended mussel communities in oligotrophic fjords, PhD-thesis. Wageningen University, The Netherlands.

Jiang, Z., Wang, G., Fang, J., \& Mao, Y. (2013). Growth and food sources of Pacific oyster Crassostrea gigas ntegrated culture with sea bass Lateolabrax japonicas in Ailian Bay, China. Aquaculture International, 21, 45-52.

Jones, T. O., \& Iwama, G. K. (1991). Polyculture of the Pacific oyster, Crassostrea gigas (Thurnberg) with chinook salmon, Oncorhynchus tschawytscha. Aquaculture, 92, 313-322.

Kang, J. H., Kim, S., Joon-Baek, L., Chung, I. K., \& Park, S. R. (2014). Nitrogen biofiltration capacities and photosynthetic activity of Pyropia yezoensis Ueda (Bangiales, Rhodophyta): groundwork to validate its potential in integrated multi-trophic aquaculture (IMTA). Journal of Applied Phycology, 26, 947-955.

Kautsky, N., Troell, M., \& Folke, C. (1999). Ecological engineering for increased production and environmental improvement in open sea aquaculture. Ecological Engineering for Wastewater Treatment, 11, 89-97.

Kawashima, Y., \& Tokuda, H. (1993). Regeneration from the callus of Undaria pinnatifida (Harvey) Suringar (Laminariales, Phaeo-phyta). Hydrobiologia, 260(261), 385-389.

KEPCO, \& KIOST. (2016). Co-location of fisheries with offshore wind farm: An overview of research carried out in KEPCO Research Institute \& KIOST. Korea Electric Power Cooperation-Research Institure (KEPCO) and Korean Institute of Ocean Science and Technology (KIOST).

KFM. (2014). Kames Fish Farming Ltd., Trial offshore seaweed longlines, Kilmelford-Argyll (Scotland/UK). Accessed June 2, 2016.

Kim, S. K. (2011). Marine cosmeceuticals. Trends and prospects. Boca Raton: CRC.

Kim, S.-K. (2012). In Handbook of marine macroalgae: Biotechnology and applied phycology (592 p). Wiley-Blackwell.

Kim, J. K., Duston, J., Corey, P., \& Garbary, D. J. (2013). Marine finfish effluent bioremediation: Effects of stocking density and temperature on nitrogen removal capacity of Chondrus crispus and Palmaria palmata (Rhodophyta). Aquaculture, 414-415, 210-216.

Kim, J. K., Kraemer, G. P., Neefus, C. D., Chung, I. K., \& Yarish, C. (2007). Effects of temperature and ammonium on growth, pigment production and nitrogen uptake by four species of Porphyra (Bangiales, Rhodophyta) native to the New England coast. Journal of Applied Phycology, 19, 431-440.

Kim, J. K., Kraemer, G. P., \& Yarish, C. (2014a). Field scale evaluation of seaweed aquaculture as a nutrient bioextraction strategy in Long Island Sound and the Bronx River Estuary. Aquaculture, 433, 148-156.

Kim, J. K., Kraemer, G. P., \& Yarish, C. (2015a). Sugar Kelp aquaculture in long island sound and the Bronx River Estuary for nutrient bioextraction associated with biomass production. Marine Ecology progress series (in press).

Kim, J. K., Mao, Y., Kraemer, G. P., \& Yarish, C. (2015b). Growth and pigment content of Gracilaria tikvahiae under fluorescent and LED lighting. Aquaculture, 436, 52-57.

Kim, G. H., Moon, K.-H., Kim, J.-Y., Shim, J., \& Klochkova, T. A. (2014b). A revaluation of algal diseases in Korean Pyropia (Porphyra) sea farms and their economic impact. Algae, 29, 249-265.

Kraemer, G. P., Kim, J. K., \& Yarish, C. (2014). Seaweed aquaculture: Bioextraction of nutrients to reduce eutrophication. Association of Massachusetts Wetland Scientists Newsletter, 89, 16-17. 
Krause, G., Buck, B. H., \& Rosenthal, H. (2003). Multifunctional use and environmental regulations: Potentials in the offshore aquaculture development in Germany, rights and duties in the coastal zone, multidisciplinary scientific conference on sustainable coastal zone management, 12-14 June 2003, Stockholm (Sweden).

Lagerveld, S., Röckmann, C., Scholl, M. (2014). Combining offshore wind energy and large-scale mussel farming: Background and technical, ecological and economic considerations. IMARES Wageningen UR, Report C056/14. 117 pp.

Lander, T., Barrington, K., Robinson, S., MacDonald, B., \& Martin, J. (2004). Dynamics of the blue mussel as an extractive organism in an integrated multi-trophic aquaculture system. Bulletin-Aquaculture Association of Canada, 104, 19-28.

Langan, R. (2009). Opportunities and challenges for offshore farming (Chapter 29). In G. Burnell \& G. Allen (Eds.), New technologies in aquaculture: Improving production efficiency, quality and environmental management. Cambridge, UK: Woodhead Publishing Limited.

Langan, R., \& Horton, F. (2005). Design, operation and economics of submerged longline mussel culture in the open ocean. In Proceedings of the Special Sessions on Offshore Aquaculture and Progress in Commercialization of New Species Held at Aquaculture Canada ${ }^{\mathrm{TM}}$ in Victoria, $B C$, October 2003. No. 103-3, pp. 11-20.

Langlois, J., Sassi, J.-F., Jard, G., Steyer, J.-P., Delgenes, J.-P., \& Hélias, A. (2012). Life cycle assessment of biomethane from offshore cultivated seaweed. Biofuels, Bioproducts and Biorefining, 6, 387-404.

Lapointe, G. (2013). NROC white paper: Overview of the aquaculture sector in New England. 25 p.

Lasserre, T., \& Delgenès, J. P. (2012). WindSeaFuel: Production de macro-algues pour une valorisation en méthane et autres bioproduits. ANR Bioénergies 2009 Poster, ANR-09-BIOE-05, Label pôle, DERBI-TRIMATEC.

Lee, S., \& Hwang, H. (2013). Numerical simulation on dynamic characteristics of offshore seaweed culture facility. Journal of Ocean Engineering and Technology, 27, 7-15.

Lefebvre, S., Barille, L., \& Clerc, M. (2000). Pacific oyster (Crassostrea gigas) feeding responses to a fish-farm effluent. Aquaculture, 187, 185-198.

Levine, I. A., \& Sahoo, D. (2010). Porphyra: Harvesting gold from the sea. Ltd: I.K. International Publihing House Pvt. 92p.

Li, X. J., Cong, Y. Z., Yang, G. P., Qu, S. C., Li, Z. L., Wang, G. W., et al. (2009). Trait evaluation and trial cultivation of Dongfang No. 2, the hybrid of a male gametophyte clone of Laminaria longissima (Laminariales, Phaeophyta) and a female one of L. japonica. JOurnal of Applied Phycology, 19, 303-311.

Liu, D. Y., Keesing, J. K., Xing, Q. G., \& Ping, S. (2009). World's largest macroalgal bloom caused by expansion of seaweed aquaculture in China. Marine Pollution Bulletin, 58, 888-895.

Liu, F., Pang, S. J., Chopin, T., Gao, S., Shan, T., Zhao, X., et al. (2013). Understanding the recurrent large-scale green tide in the Yellow Sea: Temporal and spatial correlations between multiple geographical, aquacultural and biological factors. Marine Environmental Research, $83,38-47$.

Lüning, K., Buchholz, C. (1996). Massenkultur Mariner Makroalgen bei Helgoland zur Gewinnung von Phycokolloiden und zur Verwendung als Biosorptionsmittel. BAH Report Helgoland. 75 pp.

Marfaing, H. (2014). WinSeaFuel project: Biomethane and other bio product developments from offshore seaweed culture. In 21st International Seaweed Symposium of the International Seaweed Association, April 21-26, 2013, Bali (Indonesia) (abstract).

Marinho, G. S., Holdt, S. L., Birkeland, M. J., \& Angelidaki, I. (2015). Commercial cultivation and bioremediation potential of sugar kelp, Saccharina latissima, in Danish waters. Journal of Applied Phycology. doi:10.1007/s10811-014-0519-8

Martinez-Aragon, J. F., Hernandez, I., Perez-Llorens, J. L., Vazquez, R., \& Vergara, J. J. (2002). Biofiltering efficiency in removal of dissolved nutrients by three species of estuarine macroalgae cultivated with sea bass (Dicenntrarchus labrax) waste waters: 1 Phosphate. Journal of Applied Phycology, 14, 365-374.

Matthiessen, G. C. (2001). Oyster culture. Fishing News Books. 172 p. 
Mazzola, A., \& Sara, G. (2001). The effect of fish farming organic waste on food availability for bivalve molluscs (Gaeta Gulf, Central Tyrrhenian, MED): Stable carbon isotopic analysis. Aquaculture, 192, 361-379.

McVey, J., \& Buck, B. H. (2008). IMTA-design within an offshore wind farm. Aquaculture for human wellbeing-The Asian perspective. The annual meeting of the world aquaculture society, 23rd May, 2008, Busan, Korea.

McVey, J. P., Stickney, R. R., Yarish, C., \& Chopin, T. (2002). Aquatic polyculture balanced ecosystem management: New paradigms for seafood production. In R. R. Stickney \& J. P. McVey (Eds.), Responsible marine aquaculture (pp. 91-104). World Aquaculture Society.

Miura, A. (1984). A new variety and a new form of Porphyra (Bangiales, Rhodophyta) from Japan: Porphyra tenera Kjellman var. tamatsuensis Miura, var. nov. and P. yezoensis Ueda form. narawaensis Miura, form. nov. Journal of the Tokyo University of Fisheries, 71, 1-3.

Moura, S., Lipsky, A., \& Morse, M. (2011). Options for cooperation between commercial fishing and offshore wind energy industries: A review of relevant tools and best practices. SeaPlan, $41 \mathrm{p}$.

Msuya, F. E., \& Neori, A. (2008). Effect of water aeration and nutrient load level on biomass yield, $\mathrm{N}$ uptake and protein content of the seaweed Ulva lactuca cultured in seawater tanks. Journal of Applied Phycology, 20, 1021-1031.

Mugg, J., Serrano, A., Liberti, A., \& Rice, M. A. (2000). Aquaculture effluent: A guide for water quality regulators and aquaculturalists. Northeast Regional Aquaculture Center. Publication No. 00-003.

NASA. (2015). NASA, NOAA find 2014 warmest year in modern record. Accessed May 2, 2016, at http://www.giss.nasa.gov/research/news/20150116/

Navarrete-Mier, F., Sanz-Lázaro, C., \& Marín, A. (2010). Does bivalve mollusc polyculture reduce marine fin fish farming environmental impact? Aquaculture, 306, 101-107.

Neori, A., Chopin, T., Troell, M., Buschmann, A. H., Kraemer, G., Halling, C., et al. (2004). Integrated aquaculture: Rationale, evolution and state of the art emphasizing seaweed biofiltration in modern aquaculture. Aquaculture, 231, 361-391.

Neori, A., Shpigel, M., \& Ben-Ezra, D. (2000). A sustainable integrated system for culture of fish, seaweed and abalone. Aquaculture, 186, 279-291.

Neori, A., Troell, M., Chopin, T., Yarish, C., Critchley, A., \& Buschmann, A. H. (2007). The need for a balanced ecosystem approach: Blue revolution aquaculture. Environment, 49, 36-43.

Niwa, K., Iida, S., Kato, A., Kawai, H., Kikuchi, N., Kobiyama, A., et al. (2009). Genetic diversity and introgression in two cultivated species (Porphyra yezoensis and Porphyra tenera) and closely related wild species. Journal of Phycology, 45, 493-502.

Nunes, J. P., Ferreira, J. G., Gazeau, F., Lenceart-Silva, J., Zhang, X. L., Zhu, M. Y., et al. (2003). A model for sustainable management of shellfish polyculture in coastal bays. Aquaculture, 219, 257-277.

Ögmundarson, Ó., Holmyard, J., Pórðarson, G., Sigurðsson, F., \& Gunnlaugsdóttir, H. (2011). Offshore aquaculture farming - Report from the initial feasibility study and market requirements for the innovations from the project. Matís ohf/Matís Food research, Innovation and Safety.

Pearce, D. W., \& Turner, R. K. (1989). Economics of natural resources and the environment. Johns Hopkins University Press.

Peharda, M., Zupan, I., Bavcevic, L., Frankic, A., \& Klanjscek, T. (2007). Growth and condition index of mussel Mytilus galloprovincialis in experimental integrated aquaculture. Aquaculture Research, 38, 1714-1720.

Peng, Y., Xie, E., Zheng, K., Fredimoses, M., Yang, X., \& Zhou, X. (2013). Nutritional and chemical composition and antiviral activity of cultivated seaweed Sargassum naozhouense Tseng et Lu. Marine Drugs, 11, 20-32.

Pereira, R., \& Yarish, C. (2008). Mass production of marine macroalgae. In S. E. Jørgensen \& B. D. Fath (Eds.), Ecological engineering. Vol. [3] of Encyclopedia of Ecology (5 Vols., pp. 2236-2247) Oxford: Elsevier. 
Pereira, R., \& Yarish, C. (2010). The role of Porphyra in sustainable culture systems: Physiology and applications. In A. Israel \& R. Einav (Eds.), Role of seaweeds in a globally changing environment (pp. 339-354). Springer Publishers.

Pogoda, B., Buck, B. H., \& Hagen, W. (2011). Growth performance and condition of oysters (Crassostrea gigas and Ostrea edulis) farmed in an offshore environment (North Sea, Germany). Aquaculture, 319, 484-492.

Pogoda, P., Buck, B. H., Saborowski, R., \& Hagen, W. (2013). Biochemical and elemental composition of the offshore cultivated oysters Ostrea edulis and Crassostrea gigas. Aquaculture, 319, 53-60.

Pogoda, B., Jungblut, S., Buck, B. H., \& Hagen, W. (2012). Parasitic infestations of copepods in oysters and mussels: Differences between nearshore wild banks and an offshore cultivation site in the German Bight. Journal of Applied Ichthyology, 28, 756-765.

Rawson, M. V., Jr., Chen, C., Ji, R., Zhu, M., Wang, D., Wang, L., et al. (2002). Understanding the interaction of extractive and fed aquaculture using ecosystem modeling. In R. R. Stickney \& J. P. McVey (Eds.), Responsible marine aquaculture (pp. 263-2961). Oxon: CABI Publishing.

Redmond, S., Kim, J. K., Yarish, C., Pietrak, M., \& Bricknell, I. (2014). Culture of Sargassum in Korea: Techniques and potential for culture in the U.S. Orono, ME: Maine Sea Grant College Program. Retreived April 2, 2016, from seagrant.umaine.edu/extension/korea-aquaculture

Reid, G. K., Robinson, S. M. C., Chopin, T., \& MacDonald, B. A. (2013). Dietary Proportion of Fish Culture Solids Required by Shellfish to Reduce the Net Organic Load in Open-Water Integrated Multi-Trophic Aquaculture: A Scoping Exercise with Cocultured Atlantic Salmon (Salmo salar) and Blue Mussel (Mytilus edulis). Journal of Shellfish Research 32(2): 509-517.

Rensel J., Bright K., King, G., \& Siegrist Z. (2011). Integrated fish-shellfish mariculture in Puget Sound. NOAA Final report. 3-31-2011. NA08OAR4170860.

Ridler, N., Robinson, B., Chopin, T., Robinson, S., \& Page, F. (2006). Development of integrated multi-trophic aquaculture in the Bay of Fundy, Canada: A socio-economic case study. Journal of the World Aquaculture Society, 37, 43-48.

Ridler, N., Wowchuk, M., Robinson, B., Barrington, K., Chopin, T., Robinson, S., et al. (2007). Integrated multi-trophic aquaculture (IMTA): A potential strategic choice for farmers. Aquaculture Economics and Management, 11, 99-110.

Robertson-Anderssonm, D. V., Wilson, D. T., Bolton, J. J., Anderson, R. J., \& Maneveldt, G. W. (2009). Rapid assessment of tissue nitrogen in cultivated Gracilaria gracilis (Rhodophyta) and Ulva lactuca (Chlorophyta). African Journal of Aquatic Science, 34, 169-172.

Robinson, S. M. C., Lander, T., Martin, J. D., Bennett, A., Barrington, K., Reid, et al. (2007). An interdisciplinary approach to the development of integrated multi-trophic aquaculture (IMTA): The organic extractive component. In Proceedings of Conference on Aquaculture. World Aquaculture Society, 786 pp.

Robinson, N., Winberg, P., \& Kirkendale, L. (2013). Genetic improvement of macroalgae: Status to date and needs for the future. Journal of Applied Phycology, 25, 703-716.

Sahoo, D., \& Ohno, M. (2003). Culture of Kappaphycus alvarezii in deep water and nitrogen enriched medium. Bulletin of Marine Sciences and Fisheries, 22, 89-96.

Sahoo, D., \& Yarish, C. (2005). Mariculture of seaweeds. In R. Andersen (Ed.), Phycological methods: Algal culturing techniques (pp. 219-237). New York: Academic Press.

Sara, G., Zenone, A., \& Tomasello, A. (2009). Growth of Mytilus galloprovincialis (mollusca, bivalvia) close to fish farms: A case of integrated multi-trophic aquaculture within theTyrrhenian Sea. Hydrobiologia, 636, 129-136.

Schaffelke, B. (2001). Surface alkaline phosphatase activities of macroalgae on coral reefs of the central Great Barrier Reef Australia. Coral Reefs, 19, 310-317.

Schaffelke, B., \& Klumpp, D. W. (1998). Nutrient-limited growth of the coral reef macroalga Sargassum baccularia and experimental growth enhancement by nutrient addition in continuous flow culture. Marine Ecology Progress Series, 164, 199-211.

Seaman, M. N. L., \& Ruth, M. (1997). The molluscan fisheries of Germany. NOAA Technical Report NMFS, 129, 57-84. 
Searle, J. P., \& Rovira, J. (2008). Cambio climático y efectos en la biodiversidad: el caso chileno. Biodiversidad de Chile: patrimonio y desafios (3rd ed, pp. 502-503). Santiago: CONAMA.

Seed, R., \& Suchanek, T. H. (1992). Population and community ecology of Mytilus. In E. Gosling (Ed.), The mussel Mytilus: Ecology, physiology, genetics and culture (87-169 pp). Development in aquaculture and fisheries science No. 25. Amsterdam, London, New York, Tokyo: Elsevier.

Serramalera, L. (2015). Adaptive capacity of aquaculture: Insights from the Chilean mussel industry. Master thesis, Erasmus mundus Master Programme EMBC.

SES. (2015a). Patented seaweed carrier system by SES, Patent No. EP 09836 439.1. SESSeaweed Energy Solutions, Trondheim (Norway).

SES. (2015b). Seaweed carrier system for the cultivation of macroalgae in offshore environments patented by SES - Seaweed Energy Solutions, Trondheim (Norway).

Shin, J.-A. (1999). Crossing between Porphyra yezoensis and P. tenera. Algae, 14, 73-77.

Shin, J.-A. (2003). Inheritance mode of some characters of Porphyra yezoensis (Bangiales, Rhodophyta) II. Yield, photosynthetic pigment content, red rot disease-resistance, color, luster and volatile sulfur compounds concentration. Algae, 18, 83-88.

Shumway, S. E. (2011). Shellfish Aquaculture and the Environment (528 p.). Wiley-Blackwell.

Skjermo, J., Aasen, I. M., Arff, J., Broch, O. J., Carvajal, A., Christie, H., et al. (2014). A new Norwegian bioeconomy based on cultivation and processing of seaweed: Opportunities and R\&D needs. SINTEF Fisheries and Aquaculture 2014-06-03. 46 pp.

Smit, A. J. (2004). Medicinal and pharmaceutical uses of seaweed natural products: A review. Journal of Applied Phycology, 16, 245-262.

Sohn, C. H. (1998). The seaweed resources of Korea. In A. T. Critchley \& M. Ohno (Eds.), Seaweed resources of the world (pp. 15-33). Yokosuka: Japan International Cooperation Agency.

Stephenson, K., \& Shabman, L. (2011). Rhetoric and reality of water quality trading and the potential for market-like reform. Journal of the American Water Resources Association, 47, $15-28$.

Stirling, H. P., \& Okumus, I. (1995). Growth and production of mussels (Mytilus edulis) suspended at salmon cages and shellfish farms in two Scottish sea lochs. Aquaculture, 134, 193-210.

Sutherland, J. E., Lindstrom, S. C., Nelson, W. A., Brodie, J., Lynch, M. D. J., Hwang, M. S., et al. (2011). A new look at an ancient order: Generic revision of the Bangiales (Rhodophyta). Journal of Phycology, 47, 1131-1151.

Syvret, M., Fitzgerald, A., Gray, M., Wilson, J., Ashley, M., \& Jones, C. E. (2013). Aquaculture in Welsh offshore wind farms: A feasibility study into potential cultivation in offshore windfarm sites. Report for the Shellfish Association of Great Britain.

Tassetti, A., Malaspina, S., \& Fabi, G. (2015). Using a multibeam echosounder to monitor an artificial reef. The International Archives of Photogrammetry, Remote Sensing and Spatial Information Sciences, XL-5/W5 (2015 Underwater 3D recording and modeling, April 16-17, 2015, Piano di Sorrento, Italy).

Tedesco, M. A., Swanson, R. L., Stacey, P. E., Latimer, J. S., Yarish, C., \& Garza, C. (2014). Synthesis for management. In J. S. Latimer, M. A. Tedesco, R. L. Swanson, C. Yarish, P. E. Stacey, \& C. Garza (Eds.), Long island sound: Prospects for the urban sea (pp. 481539). New York: Springer.

Troell, M., Chopin, T., Reid, G., Robinson, S., \& Sarà, G. (2011). Letter to the editor: Finfish-shellfish integrated multi-trophic aquaculture: Variable efficiency or experimental design issues? Aquaculture, 313, 171-172.

Troell, M., Hailing, C., Neori, A., Buschmann, A. H., Chopin, T., Yarish, C., et al. (2003). Integrated mariculture: Asking the right questions. Aquaculture, 226, 69-90.

Troell, M., Joyce, A., Chopin, T., Neori, A., Buschmann, A. H., \& Fang, J. G. (2009). Ecological engineering in aquaculture: Potential for integrated multi-trophic aquaculture (IMTA) in marine offshore systems. Aquaculture, 297, 1-9. 
Troell, M., \& Norberg, J. (1998). Modelling output and retention of suspended solids in an integrated salmon-mussel culture. Ecological Modelling, 110, 65-77.

TROPOS. (2015). Aquaculture pilot scale report. Hellenic Center for Marine Research, Modular multi-use deep water offshore platform harnessing and servicing Mediterranean, subtropical and tropical marine and maritime resources-TROPOS Project, Grant Agreement Number 288192. 40 pp.

van den Burg, S., Jak, R., Smits M.-J., de Blaeij, A., Rood, T., Blanken H., et al. (2016). Zeewier en natuurlijk kapitaal; Kansen voor een biobased economy. Wageningen, LEI Wageningen UR (University \& Research centre), LEI Rapport 2016-049. 36 blz.

van den Burg, S. W. K., Stuiver, M., Veenstra, F. A., Bikker, P., Lopez-Contreras, A. M., Palstra, A. P., et al. (2013). Triple P review of the feasibility of sustainable offshore seaweed production in the North Sea. Lei Wageningen UR. Lei Reports 13, 77, 105 pp.

Verhaeghe, D., Delbare, D., \& Polet, H. (2011). Haalbaarheidsstudie passieve visserij en maricultuur binnen de Vlaamse windolenparken? ILVO-mededeling Nr. 99, 136 pp.

Vigin, L., Devolder, M., \& Scory, S. (2016). Kaart van het gebruik van de Belgische zeegebieden - Carte de l'usage des espaces marins belges. Brügge: Royal Belgian Institute for Natural Sciences.

Voskamp, P. (2010). Mussel experiment bears fruit in deep water southeast of the island. Times: Block Island. $1 \mathrm{p}$.

Wallace, J. F. (1980). Growth rates of different populations of the edible mussel, Mytilus edulis, in north Norway. Aquaculture, 19, 303-311.

Wiencke, C., \& Bischof, K. (2012). Seaweed Biology—novel insights into ecophysiology, ecology and utilization. Berlin and Heidelberg: Springer. 514 p.

Xie, E., Liu, D., Jia, C., Chen, X. L., \& Yang, B. (2013). Artificial seed production and cultivation of the edible brown alga Sargassum naozhouense Tseng et Lu. Journal of Applied Phycology, $25,513-522$.

Zhang, J., Huo, Y., Wu, H., Yu, K., Kim, J. K., Yarish, C., et al. (2014). The origin of the Ulva macroalgal blooms in the Yellow Sea in 2013. Marine Pollution Bulletin, 89, 276-283.

Zhang, J., Kim, J. K., Yarish, C., \& He, P. (2016). The expansion of Ulva prolifera O.F. Müller macroalgal blooms in the Yellow Sea, PR China, through asexual reproduction. Marine Pollution Bulletin, 104, 101-106.

Open Access This chapter is licensed under the terms of the Creative Commons Attribution 4.0 International License (http://creativecommons.org/licenses/by/4.0/), which permits use, sharing, adaptation, distribution and reproduction in any medium or format, as long as you give appropriate credit to the original author(s) and the source, provide a link to the Creative Commons license and indicate if changes were made.

The images or other third party material in this chapter are included in the chapter's Creative Commons license, unless indicated otherwise in a credit line to the material. If material is not included in the chapter's Creative Commons license and your intended use is not permitted by statutory regulation or exceeds the permitted use, you will need to obtain permission directly from the copyright holder.

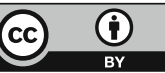

